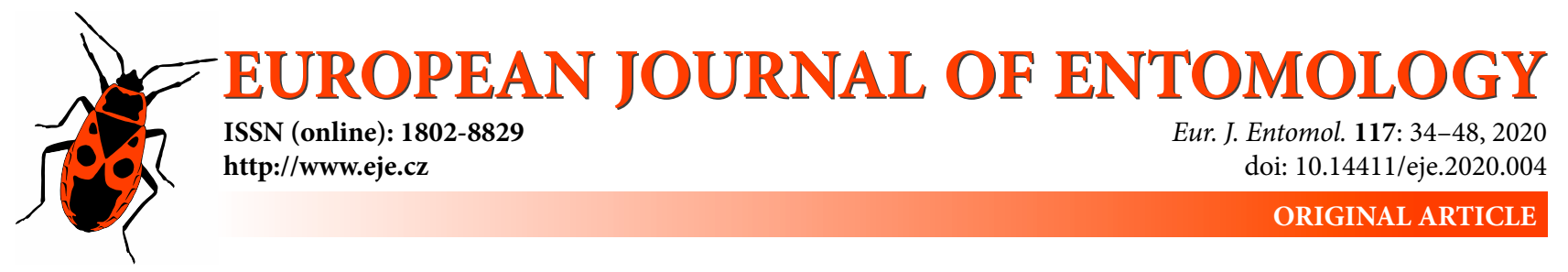

\title{
Urbanisation and forest size affect the infestation rates of plant-galling arthropods and damage by herbivorous insects
}

\author{
SANDro MEYER, HANs-Peter RUSTERHOLZ and Bruno BAUR
}

Department of Environmental Sciences, Section of Conservation Biology, University of Basel, St. Johanns-Vorstadt 10, CH-4056 Basel, Switzerland; e-mails: sandro.meyer@unibas.ch, hans-peter.rusterholz@unibas.ch, bruno.baur@unibas.ch

Key words. Urbanisation, forest size, arthropods, insects, herbivory, galls, parasitoid, chewing, mining

\begin{abstract}
Urbanisation is increasing globally and is considered to be a main driver of environmental change. Urbanisation-related factors include reduced habitat size and increased spatial isolation of the remaining habitats. As a consequence, the dynamics of plant and animal populations may change, which in turn might influence the quality and quantity of plant resources. Thus, urbanisation has the potential to disturb plant-animal interactions such as herbivory or galling. In the urban-rural setting of Basel (Switzerland), we aimed to assess whether the degree of urbanisation and forest size influence plant-galling infestation rates and leaf damage by mining and chewing arthropods on three tree species (sycamore, beech, and ash). We recorded species-specific responses to the degree of urbanisation and forest size. Gall infestation rate on sycamore leaves was affected by urbanisation but not by forest size. In contrast, gall infestation rates of beech gall midges responded sensitively to increasing urbanisation and decreasing forest size. The total leaf area damage caused by mining and chewing arthropods on sycamore was influenced by urbanisation and increased with increasing forest size. Leaf area damage by miners in beech tended to be affected by the degree of urbanisation, but not in ash. Urbanisation and forest size have the potential to alter herbivorous insect abundances. However, the effects depend on tree species and herbivore guild.
\end{abstract}

\section{INTRODUCTION}

Urbanisation is increasing globally with a projected population growth of 2.5 billion people in urban areas by 2050 (UN Urban Agenda, 2016). Urbanisation is therefore considered a major driver of environmental change (Marzluff et al., 2008; Groffman et al., 2014). The expansion of built-up areas reduces the size of natural habitat patches, increases the spatial isolation of the remaining patches and alters the environmental conditions (New, 2015). Studies along urbanisation gradients have shown increases in temperature (e.g. heat island effect) and nitrogen deposition and decreases in precipitation from rural surroundings to the city centre (McIntyre, 2000; Pickett et al., 2011). These environmental changes may influence habitat quality (McKinney, 2008) and thus alter plant species richness and composition (Schmidt et al., 2014). Furthermore, these urbanisation-related changes in environmental factors can potentially affect both the quantity (primary production) and quality (chemical composition) of the plants occurring in the habitat patches (McKinney, 2008), which in turn may influence higher trophic levels. Correspondingly, several studies revealed that urbanisation reduces species richness and changes the species composition of invertebrates (McKinney, 2008; McDonnell \& Hahs, 2015). Urbanisation-related decreases in species richness were reported in butterflies (Di Mauro et al., 2007). Martinson \& Raupp (2013) reported a decrease in species richness in carabid beetles, particularly in large, predatory and poor dispersing species and those that have strict habitat requirements. However, in the same meta-analysis, Martinson \& Raupp (2013) reported an overall neutral effect of urbanisation on coleopteran herbivores, but a negative effect on the tiny herbivores in this insect order. In contrast, several studies showed that urbanisation increased the abundances and infestation rates of herbivorous arthropods (Christie \& Hochuli, 2005; Raupp et al., 2010).

A major aspect of urbanisation is the fragmentation of natural and semi-natural habitats (Marzluff et al., 2008; Raupp et al., 2010). Some meta-analyses reveal an overall lower level of damage by herbivorous insects in fragments (Martinson \& Fagan, 2014), whereas others reported a neutral effect on overall herbivory (Rossetti et al. 2017). Fragmented forests also seem to be subjected to more pronounced edge effects than other semi-natural habitats (Marzluff et al., 2008; Dale \& Frank 2014). This assumption was confirmed by several studies, which reported both a higher abundance and species richness of herbivorous arthropods and thus a higher extent of leaf damage in forest edges than in the forest interior (Christie \& Hochuli, 2005; Guimarães et al., 2014). 
Plant-arthropod interactions are important for the structure of ecosystems, because arthropods are the most diverse and abundant plant consumers and are important prey items (McIntyre, 2000; Faeth et al., 2005; Raupp et al., 2010). Plant-galling arthropods are a good model system for assessing the response to environmental changes because of their sedentary nature and high plant host specificity (Fernandes et al., 2014), and thus are dependent on plant host quantity and quality (Cornelissen et al., 2008). A variety of organisms can induce galls, including mites, aphids, wasps and midges (Redfern et al., 2011). Galls are induced by the stimuli of feeding and/or the release of growth hormones by both the arthropod that initiates the gall and subsequently the larvae developing within the gall interacting with the defensive response of the host plant (Ananthakrishnan, 1984). Galling organisms can alter plant phenology and enhance plant quality, which can benefit other herbivorous arthropods (Ohgushi, 2005; Cornelissen et al., 2016). Plant-galling arthropods are able to create an optimal micro-climate inside their galls allowing them to regulate the humidity (Price et al., 1987; Miller III et al., 2009) and are therefore highly successful and diverse in dry environments (Fernandes \& Price, 1992). The few studies investigating the impact of urbanisation on the infestation rates of the plant-galling arthropods yielded contrasting results. McGeoch \& Chown (1997) and Mingaleva et al. (2011) reported a reduction in infestation rates of galling arthropods with urbanisation, whereas Dreistadt et al. (1990) and Sumoski et al. (2009) reported positive effects and Skrzypczyńska (2004) found an overall neutral effect of urbanisation.

Forests are one of the most frequent types of green area in cities and provide a wide range of ecosystem functions (Dwyer et al., 1992). We examined the impacts of degree of urbanisation and forest size on the occurrence and frequency of plant-galling arthropods and the extent of leaf damage by other herbivorous insects on three tree species (Acer pseudoplatanus, Fagus sylvatica and Fraxinus excelsior) in the city of Basel, Switzerland. In particular, we examined the following question: Are the infestation rates of galls and extent of grazing damage to leaves on young sycamore, beech and ash trees differently influenced by both the degree of urbanisation and size of urban forests?

\section{MATERIALS AND METHODS}

\section{Study area}

This study was carried out in the Canton of Basel-Stadt, Switzerland (hereafter referred to as Basel, $47^{\circ} 34^{\prime} \mathrm{N}, 7^{\circ} 36^{\prime} \mathrm{E}$, elevation: $245-522 \mathrm{~m}$ a.s.1.). The area studied is $37 \mathrm{~km}^{2}$, consisting of a residential area of $26.3 \mathrm{~km}^{2}(70.9 \%), 4.5 \mathrm{~km}^{2}$ of agricultural land (12.1\%), $4.4 \mathrm{~km}^{2}$ of forest (11.7\%) and $1.7 \mathrm{~km}^{2}$ of water bodies (4.5\%). It includes the city of Basel and the municipalities Riehen and Bettingen with a total of 198,206 citizens. Basel has a mean annual precipitation of $842 \mathrm{~mm}$ and mean annual temperature of $10.5^{\circ} \mathrm{C}$.

\section{Forest and landscape characteristics}

To assess the potential effects of the degree of urbanisation and forest area on the diversity of plant galls, we chose 20 mixed deciduous forests ranging in size from $258 \mathrm{~m}^{2}$ to $50,000 \mathrm{~m}^{2}$ (Table
$\mathrm{S} 1)$. These forests are embedded in a small-scale mosaic of settlements and green areas with different habitats within short distances. Historically, these forests were either part of larger forests or planted in the $19^{\text {th }}$ century (Table S1). Management of the forests (time since last thinning and management intensity) did not differ between the forests investigated. In these forests, the target tree species: sycamore (A. pseudoplatanus), European beech ( $F$. sylvatica) and ash (F. excelsior), are the most abundant species in both the tree and shrub layer. A high richness of vernal geophytes including Anemone nemorosa, Ranunculus ficaria, Polygonatum multiflorum and Arum maculatum occurs in the ground vegetation. Plant species richness and composition of the ground vegetation and in both the shrub and tree layers were determined in each forest (Melliger et al., 2017). Canopy closure was assessed using twelve photographs of each forest, which were then analysed using the pixel counting function in Adobe Photoshop (version 10.0.1). In addition, potential effects of soil characteristics on plant galls and gall infestation rates, soil moisture content (\%), total soil organic matter content (SOM) and total soil organic nitrogen were determined for each forest (Melliger et al., 2017).

To assess the degree of urbanisation, the percentage cover of sealed area within a radius of $500 \mathrm{~m}$ around the study site in each forest was determined using satellite images of each forest (Google Earth, 2009, date: 6 May 2014) and pixel counting function in Adobe Photoshop (version 10.0.1). The degree of urbanisation of the 20 forests examined ranged from $3 \%$ to $70 \%$ (Table S1).

\section{Plant gall survey}

In each forest, we established six sampling plots measuring 2 $\mathrm{m} \times 2 \mathrm{~m}$. Three of them were randomly placed at the forest edge and three in the forest interior (at least $5 \mathrm{~m}$ from the forest edge). The only criteria were that at least one of the three tree species had to occur in each plot. The inter-plot distance always exceed 5 $\mathrm{m}$. In each plot, we recorded the number of young trees (height: $30-250 \mathrm{~cm}$ ) of three species: sycamore (A. pseudoplatanus), European beech ( $F$. sylvatica) and European ash (F. excelsior). On each of these trees, we counted the number of uninfested and gallinfested leaves. Furthermore, we measured the height of each tree in each plot. Tree density was expressed as the number of trees per $4 \mathrm{~m}^{2}$ for each species in each plot. Overall, we surveyed a total of 804 trees and 41,557 leaves; 328 sycamore trees $(8,276$ leaves), 315 beech trees $(29,403$ leaves $)$ and 161 ash trees $(3,878$ leaves) in the 20 forest sites.

The galls were identified to species level using the keys of Buhr (1964/65), Redfern et al. (2011) and Bellmann (2012), with a few exceptions. Aceria cephalonea and Aceria macrorhyncha were grouped together as sycamore gall mites, while the aphid Prociphilus and the psyllids of the genus Psyllopsis were identified to genus level. The plant gall survey was conducted between 16 August and 7 September 2016.

\section{Gall mortality}

We determined the percentage of mortality of galling arthropods in a sub-sample of the infested leaves recorded for each tree species in each plot. We randomly selected six leaves from each focal tree species among all leaves infested by galls in each plot. The sampling procedure yielded 533 leaves (204 sycamore, 238 beech and 91 ash leaves) with a total of 1,099 individual galls. 863 plant galls (excluding 126 gall mite galls, 6 aphid galls and 104 psyllid galls because of the uncertainty of the identification of the inhabitants) were dissected and gall mortality type was determined according to the modified key of Kelch et al. (2016). We classified mortality as: parasitoid attack, predation, fungus infection or unknown. The classification "unknown" was given to fully 
formed galls with no inhabitant (larvae or pupae) present. Larvae and parasitoids in the plant galls were identified using the Universal Chalcidoidea Database (Noyes, 2012) and Himenòpters de Ponent (Escolà, 2012) and the parasitoid larval key in Redfern \& Askew (1992).

\section{Leaf damage}

Damage of leaves by herbivores was expressed as percentage leaf area lost and was considered as a measure of the herbivore pressure in urban forests. We randomly sampled six leaves from each focal tree species in each plot between 16 August and 7 September 2016. When there were more than six young trees (height: $30-250 \mathrm{~cm}$ ) of a particular species in a plot we randomly chose six trees and sampled a single leaf from each tree. The six leaves covered the height range of 30 to $250 \mathrm{~cm}$. When less than six young trees of a species were present in a plot (mainly ash), then we sampled two or more leaves from each tree over the entire height range. To determine the percentage leaf area removed by arthropod feeding, we used the WinDias 3.03 Image Analysis System (Delta-T Devices Ltd., UK). Leaf damage was then categorized into three types using a slightly modified classification of Gossner et al. (2014): (1) chewing damage such as circular area of damage, for example caused by adult beetles of Orchestes fagi in spring on F. sylvatica leaves, and chewing of leaf margins caused by larvae of various Lepidoptera, Symphyta and Coleoptera, or (2) damage caused by leaf mining moths and beetles. To identify the species that caused the leaf damage we used the key provided by Gossner et al. (2014) and the website http://bladmineerders.nl/ as an identification guide (Ellis, 2017).

\section{Statistical analyses}

Data analyses for each tree species were conducted separately, because beech trees did not occur in some forests. The infestation rates of plant galls was assessed at the leaf level for each of the three tree species. The percentage infestation by plant galls was calculated using the number of leaves infested divided by the total number of leaves in each plot. The infestation rate was calculated for all galls combined and for those induced by the following species: Aceria spp., Pediaspis aceris, Mikiola fagi, Hartigiola annulipes, and Psyllopsis sp., separately. The galling-arthropods Dasineura fraxini and Prociphilus sp. were only recorded in a few forests and therefore could not be considered in further analyses. The percentage of leaves damaged was first based on the number of leaves, which exhibited any sign of damage (e.g. chewing damage) divided by the total number of leaves examined. In a second approach, each leaf sampled from the three tree species was assessed for leaf damage (expressed as percentage of total area damaged). In addition, the percentage of area damaged by chewing and mining arthropods or by fungi was also determined. For data analysis, mean values were calculated for the different plant galls and leaf damage data for each of the tree species for each plot. Leaf damage caused by herbivorous arthropods, which were recorded in less than half of the forests, were omitted from this analysis.

Based on the percentage of cover of sealed area in their surroundings, the forests were classified into sites with low $(<15 \%)$, medium $(15-30 \%)$ or high $(>30 \%)$ degree of urbanisation. Forests were also assigned to one of three size classes: small $(<4,000$ $\left.\mathrm{m}^{2}\right)$, medium-sized $\left(4,000-10,000 \mathrm{~m}^{2}\right)$ or large $\left(>10,000 \mathrm{~m}^{2}\right)$ forests (Table S1). Preliminary analyses revealed that the edge factor had no effect on the overall gall infestation rate in any of the three tree species or for any of the galling arthropod species separately. Neither was there an effect on the different types of leaf damages. We therefore analysed the mean values of the data of the six plots in each forest without considering the edge factor.
We used analysis of covariance (ANCOVA) to examine potential effects of the degree of urbanisation and forest size on the infestation rate of leaves by each plant gall species separately as well as all species of galling insects combined. We used degree of urbanisation and forest size as factors, and various forests characteristics as cofactors in the ANCOVA models for all three tree species. First, we tested for inter-correlation among the explanatory variables (Table S2a-f). Variables that were not normally distributed were transformed (arcsin sqr). Percentage of sycamore leaves infested with the galls of Aceria spp. and Pediaspis aceris, percentage sycamore leaf area damage caused by chewing and mining insects and damage by Heterarthrus aceris, Heterarthrus cuneifrons and Stigmella speciosa were transformed. For beech, percentage leaf area damage by mining and by Orchestes fagi and for ash total percentage leaf area damage and percentage of damage due to mining insects and Gracillaria syringella were transformed. We checked the residuals of the ANCOVA for normal distribution using Shapiro-Wilk Normality test. The results indicated that the requirements of the model were fulfilled. The same model was used to assess the influence of the degree of urbanisation and forest size on the percentage of leaf area damaged by herbivorous arthropods and endophytic fungi. Furthermore, five frequently occurring species of galling insects and five herbivorous species were statistically analysed.

All models were stepwise reduced as recommended in Chapter 9 Statistical Modelling by Crawley (2007), but the main factors, degree of urbanisation and forest size, were always retained. We used the Tukey HSD function for multiple comparisons (post hoc tests) between the different classes of degree of urbanisation and forest size. Statistical analyses were performed using software R (R Core Team, 2015).

\section{RESULTS}

On the 328 sycamore trees, 595 out of $8,276(7.2 \%)$ leaves were infested with galls. On the 315 beech trees, 2,374 of $29,430(8.1 \%)$ leaves were infested with galls. For 161 ash trees, 179 of $3,878(4.6 \%)$ leaves were infested with galls.

\section{Effects of urbanisation and forest size on plant galls}

Degree of urbanisation affected the percentage of sycamore leaves infested by galls (Fig. 1; Table S3a). The highest gall infestation rate was recorded in forests in areas with low compared to medium and high degrees of urbanisation (Fig. 1). Similarly, the degree of urbanisation affected the percentage of beech leaves infested with $M$. fagi, but not the percentage of beech leaves infested by total galls (Fig. 2; Table S3b). For ash leaves, gall infestation rate was not influenced by the degree of urbanisation.

Forest size did not affect the percentage of sycamore leaves infested by galls (Table S3a). Considering beech, increasing forest size did not affect the percentage of leaves infested by total galls, but percentage of leaves infested with M. fagi tended to be affected by forest size (Fig. 3; Table S3b). For ash, the percentage of leaves infested by galls was not influenced by forest size (Table S3c). The degree of urbanisation and forest size interaction was not significant for any of the tree species (Table S3a-c).

The assessed forest site characteristics influenced gall infestation rate of the three tree species to a different degree. For sycamore, $P$. aceris infestation rate was significantly 


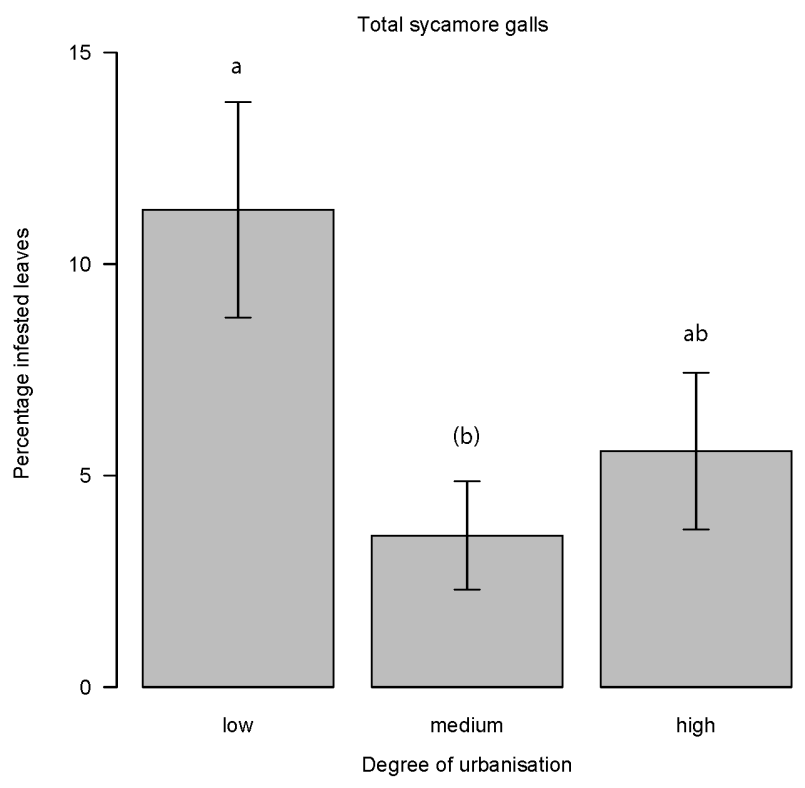

Fig. 1. The percentage of sycamore (Acer pseudoplatanus) leaves infested with galls in areas with different degrees of urbanisation. Different letters indicate significant differences among different degrees of urbanisation (low, medium, high), Tukey HSD, $\mathrm{P}<0.05$. Mean values \pm SE are presented $(n=19)$.

influenced by the total number of leaves and canopy closure (Table S3a). For beech, $M$. fagi infestation rate significantly increased with increasing plant height $\left(\mathrm{r}_{\mathrm{s}}=0.71, \mathrm{n}=\right.$ 12, $\mathrm{P}=0.010$; Table S3b). For ash, Psyllopsis sp. infestation rate tended to increase with increasing shrub species richness $\left(r_{s}=0.45, n=19, P=0.053\right.$; Table $\left.\mathrm{S} 3 \mathrm{c}\right)$.

In addition, a subset of leaves was sampled to assess the percentage mortality of the gallers. Out of a total of 863 individual galls recorded on the 346 infested leaves sampled in the 20 forest sites, 494 of galls were those of gall midges (43 D. fraxini, $300 \mathrm{H}$. annulipes, $151 \mathrm{M}$. fagi) and 369 were those of gall wasps ( $P$. aceris). The total percentage mortality of the sycamore gall wasp $P$. aceris was high (mean: 89.8\%; Table S4). The percentage mortality of the two gall midges, $M$. fagi and $H$. annulipes, recorded on beech leaves was $47.0 \%$ and $80.3 \%$, respectively (Table S4). For the ash gall midge $D$. fraxini, none of the galls collected in six forest sites were parasitized or killed by predators or fungus. However, for more than one third the galls fate was unknown $(37.4 \% ; 0-100 \%)$. Due to the uneven distribution of leaves with galls sampled in the forest, mortality could not be analysed statistically.

\section{Effects of urbanisation and forest size on leaf damage}

Overall $84 \%$ of the leaves collected were damaged ( 877 from a total of 1,044 leaves). Considering tree species, $86.2 \%$ of sycamore leaves (357 from 414 ), $80.5 \%$ of beech leaves (256 from 318) and 84.6\% of ash leaves (264 from 312) were damaged. The percentage of leaf area damaged averaged $3.8 \%$ for all three species combined $3.7 \%$ for sycamore, $3.3 \%$ beech and $4.3 \%$ ash). Damage by chewing insects was the most common type $(54.7 \%$ leaves damaged; $4.4 \%$ leaf area damaged); followed by mining

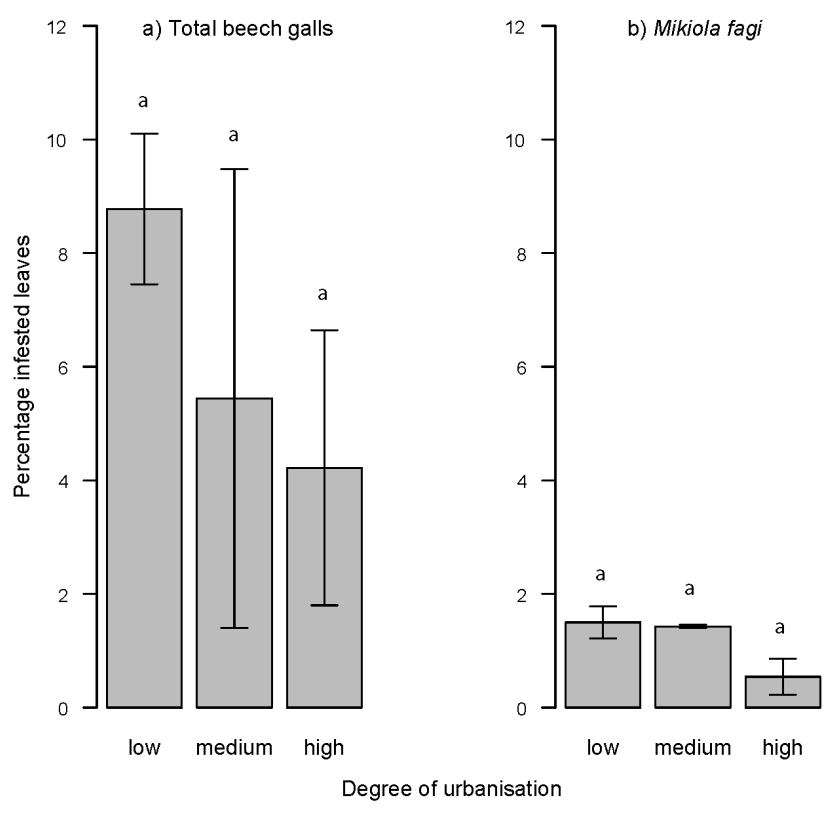

Fig. 2. The percentage of beech tree (Fagus sylvatica) leaves infested with total galls (a) and those of the gall midge Mikiola fagi (b) in areas with different degrees of urbanisation. Different letters indicate significant differences among different degrees of urbanisation (low, medium, high), Tukey HSD, $\mathrm{P}<0.05$. Mean values \pm SE are presented $(n=12)$.

$(26.2 \% ; 5.0 \%)$; and lastly by fungi $(3.2 \% ; 2.8 \%)$. Mean leaf area damaged was not correlated with gall infestation rate in any of the three tree species (in all cases $\mathrm{P}>0.23$; Fig. S1a-c).

Damage by nine herbivore and two fungal species were recorded on sycamore leaves (Table S5). The most common damage on sycamore leaves were caused by the saw-

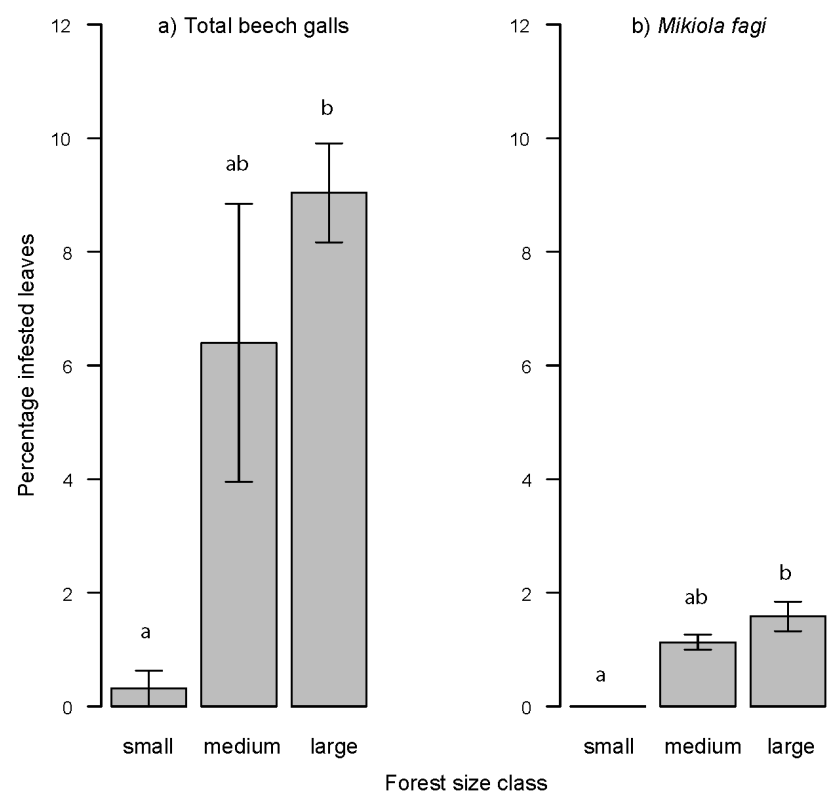

Fig. 3. The percentage of beech tree (Fagus sylvatica) leaves infested with total galls (a) and those of the gall midge Mikiola fagi (b) in different sized forests. Different letters indicate significant differences among different forest sizes (small, medium, large), Tukey HSD, $P<0.05$. Mean values $\pm S E$ are presented $(n=12)$. 

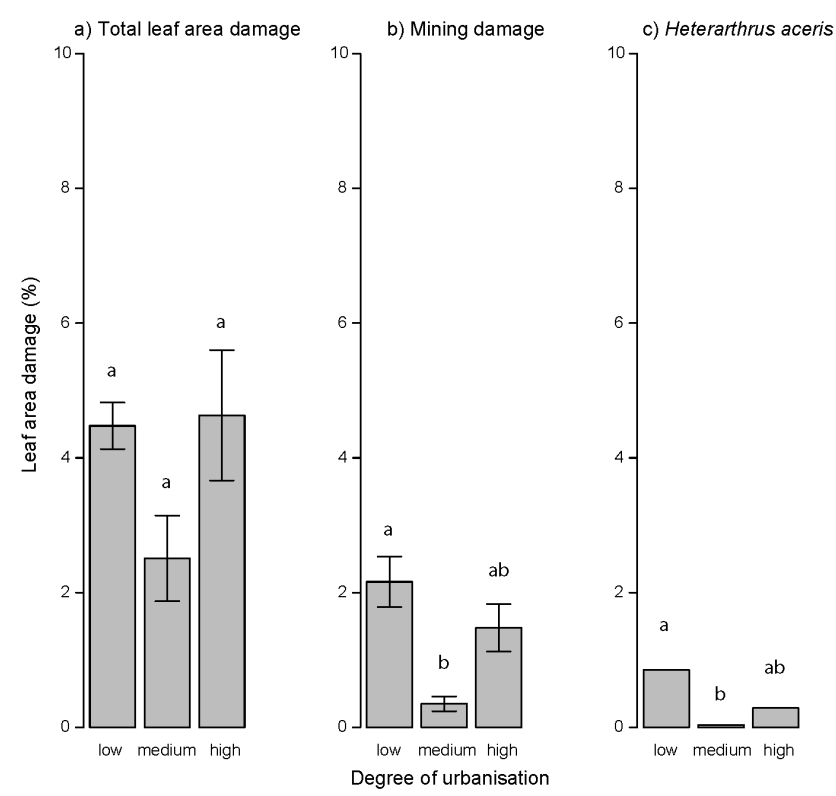

Fig. 4. The percentage of total leaf area damaged on sycamore (Acer pseudoplatanus) (a), the percentage of leaf area damaged by mining arthropods (b) and the percentage leaf area damaged by the sawfly Heterarthrus aceris (c) in areas with different degrees of urbanisation. Different letters indicate significant differences among different degrees of urbanisation (low, medium, high), Tukey HSD, $P<0.05$. Mean values \pm SE are presented $(n=19)$.

fly Heterarthrus cuneifrons $(10.4 \%$; $0.49 \%$; percentage of leaves damaged and mean percentage of leaf area damaged), the moth Stigmella speciosa $(10.1 \%$; $0.31 \%)$, the sawfly Heterarthrus aceris $(8.7 \% ; 0.43 \%)$ and the fungus Rhytisma acerinum $(7.5 \%$; $0.17 \%)$. Damage of six herbivorous species was recorded on beech leaves. The most common damage was caused by the weevil Orchestes fagi (chewing damage: $28.9 \%$; $0.97 \%$, and mining damage: $7.2 \% ; 0.22 \%)$ and the moth Phyllonorycter maestingella $(5.7 \% ; 0.31 \%)$. On ash leaves, three species of herbivorous moths were recorded, namely Gracillaria syringella $(8.3 \% ; 1.29 \%)$, Prays fraxinella $(4.2 \% ; 0.13 \%)$ and $\mathrm{Co}-$ leophora badiipennella $(1.3 \%$; $0.02 \%$; Table S5).

Degree of urbanisation affected the total percentage of leaf area damaged in sycamore (Fig. 4; Table S6a). Among the three damage types, urbanisation affected the percentage of leaf area damaged by mining insects. Furthermore, the percentage of leaf area damaged by the sawfly Heterarthrus aceris was influenced by the degree of urbanisation (Fig. 4; Table S6a). For beech and ash, the degree of urbanisation did not influence the percentage of leaf area damaged (Table S6b, c).

Increasing forest size significantly increased the total percentage of leaf area damage on sycamore (Fig. 5; Table S6a). The same pattern was found for the percentage of sycamore leaf area damaged by chewing insects. For beech and ash leaves, forest size was affected by neither total percentage leaf area damaged nor damage types. The significant interaction between urbanisation and forest size was a result of a lower incidence of chewing damage in small forests than in large forests in highly urbanised areas (Table S6b).

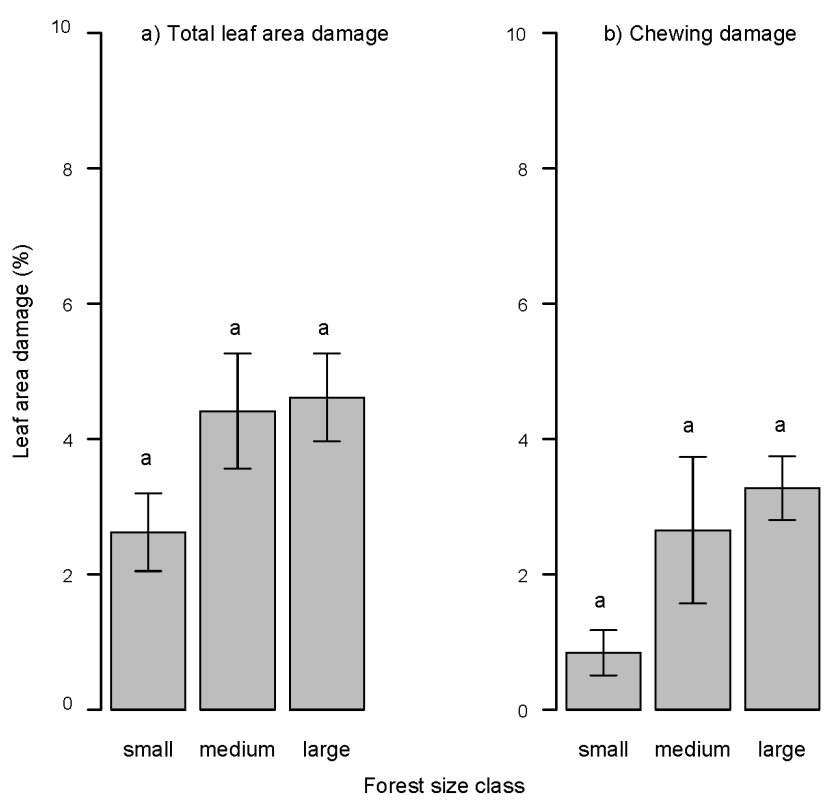

Fig. 5. The percentage of total leaf area damaged on sycamore (Acer pseudoplatanus) (a) and the percentage of leaf area damaged by chewing arthropods (b) in different sized forests. Different letters indicate significant differences among different forest sizes (small, medium, large), Tukey HSD, $\mathrm{P}<0.05$. Mean values $\pm \mathrm{SE}$ are presented $(n=19)$.

Environmental characteristics of forest sites influenced leaf area damage in various ways. Considering sycamore, chewing leaf area damage was influenced by total number of leaves and increased with increasing canopy closure $\left(\mathrm{r}_{\mathrm{s}}\right.$ $=0.48, \mathrm{n}=19, \mathrm{P}=0.041$; Table S6a). For beech, mining damage was affected by tree richness and positively correlated with tree density $\left(r_{\mathrm{s}}=0.75, \mathrm{n}=12, \mathrm{P}=0.005\right.$; Table S6b). Regarding ash, total leaf area damage was influenced by tree richness and increased with increasing soil moisture $\left(r_{s}=0.62, n=19, P=0.006\right.$; Table S6c). Furthermore, chewing leaf area damage of ash was influenced by total number of leaves and was positively correlated with soil moisture $\left(r_{s}=0.48, n=19, P=0.041\right)$. Ash mining leaf area damage and damage by G. syringella was influenced by tree richness (Table S6c).

\section{DISCUSSION}

\section{Effects of urbanisation and forest size on plant galls}

Our study showed both tree species-specific and arthropod species-specific responses of gall infestation to the degree of urbanisation and forest size. For beech trees, the gall infestation rate at the leaf level $(7.0 \%)$ reported here is similar to that reported in a German beech forest $(10 \%$; Gossner et al., 2014), but lower than in a beech forest in Poland (35\%; Pilichowski \& Giertych, 2018). Gall infestation rate was, however, slightly higher than the average of $4.4 \%$ recorded in temperate forests (Kozlov et al., 2015).

In this study, an increase in the degree of urbanisation had a negative effect on gall infestation rates, especially for the beech gall midge M. fagi. Although some galling species may be found to be more prevalent in urban areas 
(Frankie et al., 1987), our result is consistent with findings of McGeoch \& Chown (1997) and Mingaleva et al. (2011), who report an overall reduction in gall infestation rate on seven tree species in urban areas (but these studies did not investigate beech, Fagus sylvatica) and Segebade \& Schaefer (1979), who found M. fagi to be completely absent in urban trees. In sycamore trees, our result that leaf gall infestation was highest in low urbanised areas, contrasts previous findings of Skrzypczyńska (2004) and Segebade \& Schaefer (1979), who reported higher infestation rates of Aceria cephalonea and Aceria macrorhyncha in urban areas.

Various factors may contribute to the distribution patterns of galls, including forest fragmentation, abiotic factors such as the thermal radiation from urban environments and humidity, spatial distribution of trees, leaf quality, availability of overwintering sites and dispersal capabilities.

Several studies reported higher gall infestation rates in small forest fragments than in large forests due to edge effects resulting in increased stress of the plants (Araújo \& Espírito-Santo Filho, 2012) or increased plant vigour, reduced mortality or changes in microclimate (Akkuzu et al., 2015; Maldonado-López et al., 2015; Kelch et al., 2016). However, none of these studies were conducted in forests embedded in an urban matrix. In our study, we recorded that the infestation rate of the beech gall midge $M$. fagi was more pronounced in large than in small forests.

Forests of various sizes may also differ in their local climatic conditions. In particular, small urban forests are more subject to higher temperatures and lower humidity (Marzluff et al., 2008; Dale \& Frank, 2014), which can negatively (Valladares et al., 2006) or positively impact herbivorous insects (Youngsteadt et al., 2015). A previous study conducted in the same forest sites could not detect any temperature increase in forests in highly urbanised areas (Melliger et al., 2017), probably because forests can buffer part of the elevated temperature in urban areas (Long et al., 2019).

Galling species are able to manipulate their micro-environment, for example, by regulating the humidity inside the galls (Fernandes \& Price, 1992). Galling insects have been found to be more species-rich in xero-thermic regions in the USA and Brazil (Price et al., 1987). A vertical stratification sampling of beech leaves in a rural German beech forest showed that M. fagi infestation was not affected by differences in temperature and humidity levels (Stiegel \& Mantilla-Contreras, 2018). Although beech trees are sensitive to water deficit, $M$. fagi is probably not more vulnerable to the drier climatic conditions in small urban forests.

The gall midge $M$. fagi can exploit beech trees in a wide range of environments, which can result in potential outbreaks (Skuhravý \& Skuhravá, 1996; Urban, 2000). A higher abundance of beech trees caused overall a positive effect on gall midge incidence (Mangels et al., 2015). Similarly, the larger forests in our study had on average higher densities of beech saplings and thus higher beech gall infestation rates. In accordance, $M$. fagi gall infestation rates were positively related to tree height. These relationships can be explained by the resource concentration hypothesis (Root, 1973), which states a greater prevalence of host plants results in larger herbivore populations (Schnitzler et al., 2011).

Urban forests are frequently used for recreation, which can result in soil compaction and reduction in the amount of leaf litter (New, 2015). In the forests examined, a reduced litter biomass was recorded in small forests (Melliger et al., 2017). This may negatively impact the litter overwintering habitat for the pupae of M. fagi, as suggested by Segebade \& Schaefer (1979).

Fragmentation decreases the connectivity between habitat patches by disrupting insect movement, which reduces the probability of colonizing more isolated habitat patches (Harvey \& MacDougall, 2015). It is expected that some traits such as body size and high resource specialisation are the key factors, which result in a more pronounced negative response to spatial scale (Tscharntke \& Brandl, 2004). Therefore, it is possible that small host-plant specialist gall midges (Carneiro et al., 2009), with relatively short active dispersal ranges from 1-7 $\mathrm{m}$ for Rhopalomyia californica to $500 \mathrm{~m}$ for Sitodiplosis mosellana (Briggs \& Latto, 2000; Hao et al., 2013), could be negatively affected by increasing habitat fragmentation. A study on vertical zonation in North western Switzerland indicated that females of $M$. fagi were capable of flying up to the canopy $(>30 \mathrm{~m})$ for oviposition (Kampichler \& Teschner, 2002), but greater flight distances have not been recorded for this species. This negative fragmentation effect may be even more pronounced during passive long-distance dispersal attempts in a complex (urban) landscape than in a homogenous landscape due to a lower probability of randomly reaching a suitable habitat patch (Miao et al., 2013; Martinson \& Fagan, 2014; O'Rourke \& Petersen 2017).

According to the predator-avoidance hypothesis, urbanisation can result in a reduced parasitism rate of plantgalling arthropods in urban areas (Frankie et al., 1987; McIntyre, 2000). However, we were not able to test this hypothesis. Nonetheless, the low parasitism rate recorded in the gall midges $M$. fagi, $H$. annulipes and $D$. fraxini could be a result of their hypersensitivity (localised resistance of host plant against pathogens), being the main cause for larval mortality early in development, which prevents the possibility of parasitism (Fernandes et al., 2003; Pilichowski \& Giertych, 2017). In contrast, high parasitism rates, reported here for the sycamore gall wasp $P$. aceris (71.4-100\%) have also been reported in other gall wasps (Stone et al., 2002).

\section{Effects of urbanisation and forest size on leaf damage}

We recorded an overall high percentage ( $84 \%$ ) of leaves damaged, but low mean leaf area damaged (3.8\%) by herbivorous arthropods. Independent of different sample sizes, the extent of leaf area damages was very similar to that reported in other studies in beech forests $(80 \%$ of leaves and $6 \%$ of leaf area damaged; Gossner et al., 2014) and in urban areas $(87 \%$ of leaves and $<5 \%$ of leaf area damaged; 
Christie \& Hochuli, 2005). However, higher leaf area damages were reported in temperate regions $(7.1 \%$; Coley \& Barone, 1996; and 7.6\%; Kozlov et al., 2015).

We found host-specific responses to urbanisation, which were only significant in sycamore. The highest level of sycamore leaf damage was found in highly urbanised sites, supporting the results of other studies (e.g. Christie \& Hochuli, 2005; Raupp et al., 2010; Meineke et al., 2013). Considering exclusively sycamore and beech leaf mining damage, its extent was most pronounced in forests situated in areas with a low degree of urbanisation. This reflects findings of prior studies that showed reduced leaf damage in urban trees (Nuckols \& Connor, 1995; Mingaleva et al., 2011; Kozlov et al., 2017). This pattern was explained by predatory activity of generalists including ants and birds in urban areas (Kozlov et al., 2017). However, a study on oak herbivory found no effects of urbanisation on leaf damage by mining arthropods, but rather a $30 \%$ reduction in chewing damage in urban areas (Moreira et al., 2019). Although we could not find an overall negative effect of urbanisation on chewing damage on sycamore, the interaction with forest size revealed a combined negative effect causing a lower sycamore chewing damage level in small forests, especially in highly urbanised areas.

In our study, small forests had the lowest total leaf damage and chewing damage in sycamore. Reduced chewing damage in small forests compared to large continuous forests was also reported by Ruiz-Guerra et al. (2010). The observed reduction in leaf damage could be a result of a negative effect of fragmentation on the abundance of folivorous arthropods (Valladares et al., 2006; Martinson \& Fagan, 2014; Chávez-Pesqueira et al., 2015). Environmental variables have the potential to influence the abundance of particular leaf mining species (Raupp et al., 2010; Stiegel \& Mantilla-Contreras, 2018; Vidal \& Murphy, 2018). Our result that both the total leaf area damage on ash and chewing damage on ash were positively affected by soil moisture, contrasts previous findings of a negative relationship between urban heat stress and the extent of insect pest infestations (Meineke \& Frank, 2018).

In conclusion, our study revealed that urbanisation and forest size have the potential to disrupt plant-arthropod interactions. The varying responses of galling and other herbivorous arthropods to urbanisation and forest size may be a result of local environmental conditions, tree-specific responses as well as herbivore species-specific responses (e.g. limited dispersal capabilities, host specificity). Nevertheless, we were able to show that the effects of urbanisation and a reduction of forest size did not benefit most plant galling or herbivorous arthropods, but rather negatively impacted the infestation rates of some arthropods such as the beech galling midge, M. fagi.

ACKNOWLEDGEMENTS. We would like to thank the forest owners and foresters for allowing us access to the forests. We thank R. Askew and M. Skuhravá for advice with and help in species identification. Lastly, we would like to thank B. Braschler, T. Fayle and three anonymous reviewers for useful comments on the manuscript.
AUTHOR CONTRIBUTIONS. S. Meyer: field work, identification of arthropods, data analysis, manuscript writing; H.-P. Rusterholz: study design, data analysis, reviewed and edited the manuscript; B. Baur: study design, reviewed and edited the manuscript.

\section{REFERENCES}

Akkuzu E., DingloĞLu E. \& Unal S. 2015: Edge effects on gallinducing insect Mikiola fagi (Diptera: Cecidomyiidae) in the oriental beech forests. - Pak. J. Zool. 47: 685-690.

Ananthakrishnan T.N. 1984: Biology of Gall Insects. Edward Arnold, London, $376 \mathrm{pp}$.

AraúJo W.S. \& Espírito-SAnto Filho K. 2012: Edge effect benefits galling insects in the Brazilian Amazon. - Biodiv. Conserv. 21: 2991-2997.

Bellmann H. 2012: Geheimnisvolle Pflanzengallen. Ein Bestimmungsbuch für Pflanzen- und Insektenfreunde. Quelle \& Meyer, Wiebelsheim, 312 pp.

BRIGGS C.J. \& LATTO J. 2000: The effect of dispersal on the population dynamics of a gall-forming midge and its parasitoids. - J. Anim. Ecol. 69: 96-105.

BuHr H. 1964/1965: Bestimmungstabellen der Gallen (Zoo- und Phytocecidien) an Pflanzen Mittel- und Nordeuropas. Gustav Fischer, Jena, 761 pp.

Carneiro M.A.A., Branco C.S., Braga C.E., Almada E.D., Costa M., Maia V.C. \& Fernandes G.W. 2009: Are gall midge species (Diptera, Cecidomyiidae) host-plant specialists? Rev. Bras. Entomol. 53: 365-378.

Chávez-Pesqueira M., Carmona D., Suárez-Montes P., NúÑezFARFÁn J. \& Aguilar R. 2015: Synthesizing habitat fragmentation effects on plant-antagonist interactions in a phylogenetic context. - Biol. Conserv. 192: 304-314.

Christie F.J. \& Hochuli D.F. 2005: Elevated levels of herbivory in urban landscapes: are declines in tree health more than an edge effect? - Ecol. Soc. 10: 1-9.

Coley P.D. \& Barone J.A. 1996: Herbivory and plant defenses in tropical forests. - Annu. Rev. Ecol. Syst. 27: 305-335.

Cornelissen T., Wilson Fernandes G. \& Vasconcellos-Neto J. 2008: Size does matter: variation in herbivory between and within plants and the plant vigor hypothesis. - Oikos: 117: $1121-1130$.

Cornelissen T., Cintra F. \& Santos J.C. 2016: Shelter-building insects and their role as ecosystem engineers. - Neotrop. Entomol. 45: 1-12.

Crawley M.J. 2007: Chapter 9. Statistical Modelling. In The $R$ Book. Imperial College London at Silwood Park, pp. 323-386.

Dale A.G. \& Frank S.D. 2014: Urban warming trumps natural enemy regulation of herbivorous pests. - Ecol. Appl. 24: 1596-1607.

Di Mauro D., Dietz T. \& Rockwood L. 2007: Determining the effect of urbanization on generalist butterfly species diversity in butterfly gardens. - Urban Ecosyst. 10: 427-439.

Dreistadt S.H., Dahlsten D.L. \& Frankie G.W. 1990: Urban forests and insect ecology. - BioScience 40: 192-198.

Dwyer J.F., Mcpherson E.G., Schroeder H.W. \& Rowntree R.A. 1992: Assessing the benefits and costs of the urban forest. - J. Arboric. 18: 227-234.

EluIs W.N. 2017: Plant Parasites of Europe. Leafminers, Galls and Fungi. URL: http://bladmineerders.nl/ (last accessed September, 2017).

EsCOLÀ A.R. 2012: Himenòpters de Ponent. URL: http://ponent. atspace.org/fauna/ins/ (last accessed April, 2017).

Faeth S.H., Warren P.S., Shochat E. \& Marussich W.A. 2005: Trophic dynamics in urban communities. - BioScience 55: 399-407. 
Fernandes G.W. \& Price P.W. 1992: The adaptive significance of insect gall distribution: survivorship of species in xeric and mesic habitats. - Oecologia 90: 14-20.

Fernandes G.W., Duarte H. \& LÜtTGe U. 2003: Hypersensitivity of Fagus sylvatica L. against leaf galling insects. - Trees 17: 407-411.

Fernandes G.W., Coelho M.S. \& Santos J.C. 2014: Neotropical insect galls: Status of knowledge and perspectives. In Fernandes G.W. \& Santos J.C. (eds): Neotropical Insect Galls. Springer, New York, pp. 1-14.

Frankie G.W., Brewer J.W., Cranshaw W. \& Barthell J.F. 1987: Abundance and natural enemies of the spindle gall midge, Pinyonia edulicola Gagné, in natural and urban stands of pinyon pine in Colorado (Diptera: Cecidomyiidae). - J. Kans. Entomol. Soc. 60: 133-144.

Gossner M.M., Pašalić E., Lange M., Lange P., Boch S., HessenMÖller D., Müller J., Socher S.A., Fischer M.,Weisser W.W. ET AL. 2014: Differential responses of herbivores and herbivory to management in temperate European beech. - PLOS ONE 9(8): e104876, $16 \mathrm{pp}$.

Groffman P.M., Cavender-Bares J., Bettez N.D., Grove J.M., Hall S.J., Heffernan J.B., Hobbie S.E., Larson K.L., Morse J.L., SteEL M.K. eT AL. 2014: Ecological homogenization of urban USA. - Front. Ecol. Environ. 12: 74-81.

Guimarães C.D.D.C., Viana J.P.R. \& Cornelissen T. 2014: A meta-analysis of the effects of fragmentation on herbivorous insects. - Environ. Entomol. 43: 537-545.

Hao Y.N., Miao J., Wu Y.Q., Gong Z.J., Jiang Y.L., Duan Y., Li T., Cheng W.N. \& Cui J.X. 2013: Flight performance of the orange wheat blossom midge (Diptera: Cecidomyiidae). $-J$. Econ. Entomol. 106: 2043-2047.

HaRveY E. \& Macdougall A.S. 2015: Habitat loss and herbivore attack in recruiting oaks. - Am. Midl. Nat. 173: 218-228.

KAMPICHLER C. \& TESCHNER M. 2002: The spatial distribution of leaf galls of Mikiola fagi (Diptera: Cecidomyiidae) and Neuroterus quercusbaccarum (Hymenoptera: Cynipidae) in the canopy of a Central European mixed forest. - Eur. J. Entomol. 99: 79-84.

Kelch N.S., Neves F.S., Fernandes G.W. \& Wirth R. 2016: Mechanisms driving galling success in a fragmented landscape: synergy of habitat and top-down factors along temperate forest edges. - PLOS ONE 11(6): e0157448, 17 pp.

Kozlov M.V., Lanta V., Zverev V. \& Zvereva E.L. 2015: Global patterns in background losses of woody plant foliage to insects. — Glob. Ecol. Biogeogr. 24: 1126-1135.

Kozlov M.V., Lanta V., Zverev V., Rainio K., Kunavin M.A. \& Zvereva E.L. 2017: Decreased losses of woody plant foliage to insects in large urban areas are explained by bird predation. Glob. Chang. Biol. 23: 4354-4364.

Long L.C., D'amico V. \& Frank S.D. 2019: Urban forest fragments buffer trees from warming and pests. - Sci. Total Environ. 658: $1523-1530$.

Maldonado-López Y., Cuevas-Reyes P., Stone G.N., NievesAlDREY J.L. \& OYAMA K. 2015: Gall wasp community response to fragmentation of oak tree species: importance of fragment size and isolated trees. - Ecosphere 6: 1-15.

Mangels J., Blüthgen N., Frank K., Grassein F., Hilpert A. \& Mody K. 2015: Tree species composition and harvest intensity affect herbivore density and leaf damage on beech, Fagus sylvatica, in different landscape contexts. - PLOS ONE 10(5): e0126140, 18 pp.

Martinson H.M. \& FAGAN W.F. 2014: Trophic disruption: a meta-analysis of how habitat fragmentation affects resource consumption in terrestrial arthropod systems. - Ecol. Lett. 17: $1178-1189$
Martinson H.M. \& RaupP M.J. 2013: A meta-analysis of the effects of urbanization on ground beetle communities. - Ecosphere 4: 1-24.

Marzluff J.M., Shulenberger E., Endlicher W., Alberti M., Bradley G., Ryan C. \& Zumbrunnen C. 2008: Urban Ecology: An International Perspective on the Interaction Between Humans and Nature. Springer Science and Business Media, New York, 808 pp.

McDonnell M.J. \& Hahs A.K. 2015: Adaptation and adaptedness of organisms to urban environments. - Annu. Rev. Ecol. Evol. Syst. 46: 261-280.

McGeоch M.A. \& Chown S.L. 1997: Impact of urbanization on a gall-inhabiting Lepidoptera assemblage: The importance of reserves in urban areas. - Biodiv. Conserv. 6: 979-993.

MCINTYRE N.E. 2000: Ecology of urban arthropods: a review and a call to action. - Ann. Entomol. Soc. Am. 93: 825-835.

MCKinNeY M.L. 2008: Effects of urbanization on species richness: a review of plants and animals. - Urban Ecosyst. 11: $161-176$.

MeIneKe E.K. \& Frank S.D. 2018: Water availability drives urban tree growth responses to herbivory and warming. $-J$. Appl. Ecol. 55: 1701-1713.

Meineke E.K., Dunn R.R., Sexton J.O. \& Frank S.D. 2013: Urban warming drives insect pest abundance on street trees. PLOS ONE 8(3): e59687, 7 pp.

Melliger R.L., Rusterholz H.P. \& Baur B. 2017: Ecosystem functioning in cities: Combined effects of urbanisation and forest size on early-stage leaf litter decomposition of European beech (Fagus sylvatica L.). - Urban For. Urban Greening 28: $88-96$.

Miao J., Wu Y.Q., Gong Z.J., He Y.Z., Duan Y. \& Jiang Y.L. 2013: Long-distance wind-borne dispersal of Sitodiplosis mosellana Géhin (Diptera: Cecidomyiidae) in northern China. - J. Insect Behav. 26: 120-129.

Miller III D.G., Ivey C.T. \& Shedd J.D. 2009: Support for the microenvironment hypothesis for adaptive value of gall induction in the California gall wasp, Andricus quercuscalifornicus. —Entomol. Exp. Appl. 132: 126-133.

Mingaleva N.A., Pestov S.V. \& Zagirova S.V. 2011: Health status and biological damage to tree leaves in green areas of Syktyvkar. - Contemp. Probl. Ecol. 4: 310-318.

Moreira X., Abdala-Roberts L., Berny Mier Y., Teran J.C., Covelo F., De La Mata R., Francisco M., Hardwick B., Pires R.M., RosLin T. ET AL. 2019: Impacts of urbanization on insect herbivory and plant defences in oak trees. - Oikos 128: 113-123.

NEw T.R. 2015: Insect Conservation and Urban Environments. Springer, Cham, $260 \mathrm{pp}$.

NoYes J.S. 2012: Universal Chalcidoidea Database. Natural History Museum, London, URL: http://www.nhm.ac.uk/chalcidoids (last accessed April, 2017).

Nuckols M.S. \& ConNoR E.F. 1995: Do trees in urban or ornamental plantings receive more damage by insects than trees in natural forests? - Ecol. Entomol. 20: 253-260.

OHGUSHI T. 2005: Indirect interaction webs: herbivore-induced effects through trait change in plants. - Ann. Rev. Ecol. Evol. Syst. 36: 81-105.

O'Rourke M.E. \& Petersen M. J. 2017: Extending the 'resource concentration hypothesis' to the landscape-scale by considering dispersal mortality and fitness costs. - Agric. Ecosyst. Environ. 249: 1-3.

Pickett S.T., Cadenasso M.L., Grove J.M., Boone C.G., Groffman P.M., Irwin E., Kaushal S.S., Marshall V., Mcgrath B., Warren P. et AL. 2011: Urban ecological systems: Scientific 
foundations and a decade of progress. - J. Environ. Manag. 92: 331-362.

Pilichowski S. \& Giertych M.J. 2017: Gall abundance and leaf size as factors affecting the hypersensitive reaction in the common beech (Fagus sylvatica). - Balt. For. 23: 608-611.

Pilichowski S. \& GierTych M.J. 2018: Does Hartigiola annulipes (Diptera: Cecidomyiidae) distribute its galls randomly? — Eur. J. Entomol. 115: 504-511.

Price P.W., Fernandes G.W. \& Waring G.L. 1987: Adaptive nature of insect galls. - Environ. Entomol. 16: 15-24.

Raupp M.J., Shrewsbury P.M. \& Herms D.A. 2010: Ecology of herbivorous arthropods in urban landscapes. - Annu. Rev. Entomol. 55: 19-38.

R Core Team 2015: R: A Language and Environment for Statistical Computing. Ver. 3.0.2. R Foundation for Statistical Computing, Vienna. URL: http://www.R-project.org/.

REDFERn M. \& AsKew R.R. 1992: Plant Galls. Richmond, Slough, $104 \mathrm{pp}$.

Redfern M., Shirley P. \& Bloxham M. 2011: British Plant Galls. FSC Publications, Schrewsbury, $436 \mathrm{pp}$.

RоOт R.B. 1973: Organization of a plant-arthropod association in simple and diverse habitats: the fauna of collards (Brassica oleracea). - Ecol. Monogr. 43: 95-124.

Rossetti M.R., Tscharntke T., Aguilar R. \& BatáRy P. 2017: Responses of insect herbivores and herbivory to habitat fragmentation: a hierarchical meta-analysis. - Ecol. Lett. 20: 264-272.

Ruiz-Guerra B., Guevara R., Mariano N.A. \& Dirzo R. 2010: Insect herbivory declines with forest fragmentation and covaries with plant regeneration mode: evidence from a Mexican tropical rain forest. - Oikos 119: 317-325.

Schmidt K.J., Poppendieck H.H. \& Jensen K. 2014: Effects of urban structure on plant species richness in a large European city. - Urban Ecosyst. 17: 427-444.

Schnitzler F.R., Hartley S. \& Lester P.J. 2011: Trophic-level responses differ at plant, plot, and fragment levels in urban native forest fragments: a hierarchical analysis. - Ecol. Entomol. 36: $241-250$.

Segebade R. \& Schaefer M. 1979: Zur Ökologie der Arthropodenfauna einer Stadtlandschaft und ihrer Umgebung II.
Pflanzengallen und Pflanzenminen. - Anz. Schädlingsk. Pflanzensch. Umweltsch. 52: 117-121.

SKRZYPCZYŃSKA M. 2004: Studies on the population frequency of insects and mites causing galls on the leaves of the sycamore maple Acer pseudoplatanus L. in southern Poland. - J. Pest Sci. 77: 49-51.

SkUHRAVÝ V. \& SkUhravÁ M. 1996: Betrachtung der Gallmücken (Diptera, Cecidomyiidae) an dominanten Forstgehölzen Eurasiens nach ihrem Schädlichkeitsgrad mit einigen besonderen taxonomischen Problemen. - Anz. Schädlingsk. Pflanzensch. Umweltsch. 69: 56-58.

Stiegel S. \& Mantilla-Contreras J. 2018: Environment vs. plant ontogeny: Arthropod herbivory patterns on European beech leaves along the vertical gradient of temperate forests in Central Germany. - Insects 9: e9, 28 pp.

Stone G.N., Schönrogge K., Atkinson R.J., Bellido D. \& PuJADE-VILLAR J. 2002: The population biology of oak gall wasps (Hymenoptera: Cynipidae). - Annu. Rev. Entomol. 47: 633668.

Sumoski S.E., Johncox A.J., Althoff D.M. \& Segraves K.A. 2009: Impact of urbanization on tri-trophic interactions in an endemic scrub community. — Fla Entomol. 92: 582-587.

TscharntKe T. \& BrandL R. 2004: Plant-insect interactions in fragmented landscapes. - Annu. Rev. Entomol. 49: 405-430.

UN URBAN AgENDA 2016: URL: http://habitat3.org/the-new-urban-agenda/ (last accessed December, 2016).

URBAN J. 2000: Beech gall midge (Mikiola fagi $\mathrm{Htg}$.) and its natural enemies. - J. For. Sci. 46: 543-568.

Valladares G., Salvo A. \& Cagnolo L. 2006: Habitat fragmentation effects on trophic processes of insect-plant food webs. - Conserv. Biol. 20: 212-217.

VIDAL M.C. \& MurPhy S.M. 2018: Bottom-up vs. top-down effects on terrestrial insect herbivores: a meta-analysis. - Ecol. Lett. 21: 138-150.

Youngsteadt E., Dale A.G., Terando A.J., Dunn R.R. \& Frank S.D. 2015: Do cities simulate climate change? A comparison of herbivore response to urban and global warming. - Glob. Chang. Biol. 21: 97-105.

Received April 15, 2019; revised and accepted December 27, 2019 Published online January 29, 2020 
Table S1. Characteristics of the 20 deciduous forest sites examined. Percentage sealed area within a radius of $500 \mathrm{~m}$ was assigned to three degrees of urbanisation: low $(<15 \%)$, medium $(15-30 \%)$ or high $(>30 \%)$. The forests were categorised into three forest size classes: small $\left(<4,000 \mathrm{~m}^{2}\right)$, medium-sized $\left(4,000-10,000 \mathrm{~m}^{2}\right)$, or large $\left(>10,000 \mathrm{~m}^{2}\right)$. GPS coordinates and elevation were obtained from www.map.geo.admin.ch.

\begin{tabular}{|c|c|c|c|c|c|c|c|c|c|c|c|c|c|}
\hline Forest & $\begin{array}{c}\text { GPS } \\
\text { coordinates }\end{array}$ & $\begin{array}{l}\text { Elevation } \\
\text { (m. a.s.l.) }\end{array}$ & $\begin{array}{l}\text { Sealed area } \\
\text { within a radius } \\
\text { of } 500 \mathrm{~m} \mathrm{( \% )}\end{array}$ & $\begin{array}{c}\text { Urbanisation } \\
\text { level }\end{array}$ & $\begin{array}{l}\text { Forest } \\
\text { area } \\
\left(\mathrm{m}^{2}\right)\end{array}$ & $\begin{array}{l}\text { Forest } \\
\text { size class }\end{array}$ & $\begin{array}{l}\text { Type of } \\
\text { forest }\end{array}$ & $\begin{array}{c}\text { Forest } \\
\text { age } \\
\text { (years) }\end{array}$ & $\begin{array}{l}\text { Soil } \\
\text { organic } \\
\text { matter }\end{array}$ & $\begin{array}{c}\text { Soil } \\
\text { moisture }\end{array}$ & $\begin{array}{c}\text { Canopy } \\
\text { closure } \\
(\%)\end{array}$ & $\begin{array}{c}\text { Shrub } \\
\text { richness } \\
\text { (median) }\end{array}$ & $\begin{array}{c}\text { Tree } \\
\text { richness } \\
\text { (median) }\end{array}$ \\
\hline Bärlauchweglein & $\begin{array}{c}47^{\circ} 34^{\prime} 08^{\prime \prime} \mathrm{N} \\
7^{\circ} 39^{\prime} 06^{\prime \prime} \mathrm{E}\end{array}$ & 346 & 12 & low & 8908 & $\begin{array}{l}\text { medium- } \\
\text { sized }\end{array}$ & planted & 58 & 22.3 & 26.91 & 94.2 & 5 & 2 \\
\hline Breite & $\begin{array}{c}47^{\circ} 33^{\prime} 10^{\prime \prime} \mathrm{N} \\
7^{\circ} 36^{\prime} 51^{\prime \prime} \mathrm{E}\end{array}$ & 264 & 39 & high & 7049 & $\begin{array}{l}\text { medium- } \\
\text { sized }\end{array}$ & planted & 58 & 25.58 & 17.71 & 96 & 6.5 & 3.5 \\
\hline Chrischona & $\begin{array}{l}47^{\circ} 34^{\prime} 30^{\prime \prime} \mathrm{N} \\
7^{\circ} 40^{\prime} 35^{\prime \prime} \mathrm{E}\end{array}$ & 485 & 4 & low & 14000 & large & forest & $>200$ & 23.55 & 32.58 & 93.05 & 4 & 3 \\
\hline Friedhof Riehen T & $\begin{array}{c}47^{\circ} 33^{\prime} 56^{\prime \prime} \mathrm{N} \\
7^{\circ} 38^{\prime} 29^{\prime \prime} \mathrm{E}\end{array}$ & 276 & 25 & medium & 4234 & $\begin{array}{l}\text { medium- } \\
\text { sized }\end{array}$ & planted & 81 & 10.58 & 14.25 & 92.88 & 6 & 1.5 \\
\hline Friedhof Riehen Wald & $\begin{array}{c}47^{\circ} 33^{\prime} 49^{\prime \prime} \mathrm{N} \\
7^{\circ} 38^{\prime} 42^{\prime \prime} \mathrm{E}\end{array}$ & 304 & 12 & low & 4034 & $\begin{array}{l}\text { medium- } \\
\text { sized }\end{array}$ & forest & $>200$ & 13.12 & 21.3 & 95.5 & 6.5 & 1 \\
\hline Fürstensteinerstrasse & $\begin{array}{l}47^{\circ} 32^{\prime} 11^{\prime \prime N} \\
7^{\circ} 36^{\prime} 07^{\prime \prime} \mathrm{E}\end{array}$ & 299 & 54 & high & 3244 & small & fragment & 134 & 21.67 & 25.13 & 96.9 & 6 & 3 \\
\hline Glögglihof & $\begin{array}{c}47^{\circ} 34^{\prime} 52^{\prime \prime} \mathrm{N} \\
7^{\circ} 38^{\prime} 53^{\prime \prime} \mathrm{E}\end{array}$ & 280 & 33 & high & 5765 & $\begin{array}{l}\text { medium- } \\
\text { sized }\end{array}$ & planted & 131 & 16.76 & 22.06 & 98.3 & 5 & 3 \\
\hline Gundeldingerrain & $\begin{array}{c}47^{\circ} 32^{\prime} 17^{\prime \prime} \mathrm{N} \\
7^{\circ} 35^{\prime} 39^{\prime \prime} \mathrm{E}\end{array}$ & 301 & 44 & high & 2285 & small & planted & 74 & 16.3 & 23.91 & 95.86 & 5.5 & 3.5 \\
\hline Hohlweg & $\begin{array}{c}47^{\circ} 35^{\prime} 15^{\prime \prime} \mathrm{N} \\
7^{\circ} 39^{\prime} 57^{\prime \prime} \mathrm{E}\end{array}$ & 332 & 10 & low & 2800 & small & planted & 58 & 19.05 & 18.75 & 97.44 & 9 & 3.5 \\
\hline Jakobsbergerholz & $\begin{array}{c}47^{\circ} 31^{\prime} 57^{\prime \prime} \mathrm{N} \\
7^{\circ} 36^{\prime} 10^{\prime \prime} \mathrm{E}\end{array}$ & 305 & 44 & high & 14000 & large & fragment & 134 & 13.54 & 15.57 & 98.21 & 5.5 & 2.5 \\
\hline Jakobsbergerhölzli & $\begin{array}{l}47^{\circ} 31^{\prime} 49^{\prime \prime} \mathrm{N} \\
7^{\circ} 35^{\prime} 50^{\prime \prime} \mathrm{E}\end{array}$ & 336 & 22 & medium & 21000 & large & fragment & 134 & 13.76 & 17.93 & 97.64 & 5.5 & 2 \\
\hline Lange Erlen & $\begin{array}{c}47^{\circ} 34^{\prime} 33^{\prime \prime} \mathrm{N} \\
7^{\circ} 36^{\prime} 18^{\prime \prime} \mathrm{E}\end{array}$ & 252 & 20 & medium & 21000 & large & forest & $>200$ & 12.57 & 19.11 & 97.86 & 4.5 & 2.5 \\
\hline Linsberg & $\begin{array}{c}47^{\circ} 34^{\prime} 25^{\prime \prime} \mathrm{N} \\
7^{\circ} 39^{\prime} 52^{\prime \prime} \mathrm{E}\end{array}$ & 425 & 10 & low & 50000 & large & forest & $>200$ & 20.83 & 25.26 & 96.91 & 9 & 6 \\
\hline Maienbühl & $\begin{array}{c}47^{\circ} 35^{\prime} 18^{\prime \prime} \mathrm{N} \\
7^{\circ} 40^{\prime} 10^{\prime \prime} \mathrm{E}\end{array}$ & 349 & 3 & low & 34000 & large & forest & $>200$ & 20.18 & 23.77 & 97.14 & 2.5 & 1.5 \\
\hline Margarethenpark & $\begin{array}{l}47^{\circ} 32^{\prime} 31^{\prime \prime} \mathrm{N} \\
7^{\circ} 35^{\prime} 01^{\prime \prime} \mathrm{E}\end{array}$ & 301 & 35 & high & 19000 & large & fragment & 136 & 13.39 & 20.53 & 96.09 & 6 & 3 \\
\hline Mooswaldli & $\begin{array}{c}47^{\circ} 34^{\prime} 51^{\prime \prime} \mathrm{N} \\
7^{\circ} 39^{\prime} 37^{\prime \prime} \mathrm{E}\end{array}$ & 297 & 16 & medium & 4686 & $\begin{array}{l}\text { medium- } \\
\text { sized }\end{array}$ & fragment & 131 & 15.14 & 27.34 & 94.71 & 6 & 2.5 \\
\hline Salamanderwegli & $\begin{array}{l}47^{\circ} 35^{\prime} 05^{\prime \prime} \mathrm{N} \\
7^{\circ} 40^{\prime} 09^{\prime \prime} \mathrm{E}\end{array}$ & 317 & 8 & low & 4061 & $\begin{array}{l}\text { medium- } \\
\text { sized }\end{array}$ & planted & 95 & 13.57 & 23.2 & 97.28 & 2 & 2.5 \\
\hline Singerstrasse & $\begin{array}{l}47^{\circ} 32^{\prime} 49^{\prime \prime} \mathrm{N} \\
7^{\circ} 36^{\prime} 50^{\prime \prime} \mathrm{E}\end{array}$ & 276 & 70 & high & 1084 & small & planted & 113 & 28.09 & 14.86 & 98.1 & 2.5 & 2 \\
\hline Teich & $\begin{array}{l}47^{\circ} 35^{\prime} 12^{\prime \prime} \mathrm{N} \\
7^{\circ} 38^{\prime} 52^{\prime \prime} \mathrm{E}\end{array}$ & 275 & 17 & medium & 258 & small & planted & 58 & 18.15 & 13.86 & 93.9 & 3 & 3 \\
\hline Wenkenköpfli & $\begin{array}{c}47^{\circ} 34^{\prime} 29^{\prime \prime} \mathrm{N} \\
7^{\circ} 39^{\prime} 29^{\prime \prime} \mathrm{E}\end{array}$ & 372 & 12 & low & 36000 & large & fragment & 131 & 23.3 & 27.11 & 97.8 & 7 & 2 \\
\hline
\end{tabular}

Table S2. Inter-correlations (Spearman correlations) among tree and forest site characteristics.

\begin{tabular}{|c|c|}
\hline \multicolumn{2}{|l|}{ (a) Sycamore tree characteristics } \\
\hline Number of leaves vs. average tree height & $r_{s}=-0.27 n=19, F$ \\
\hline Number of leaves vs. density of trees & $r_{s}=0.89, n=19, P<0.001$ \\
\hline Average tree height vs. density of trees & $r_{s}=-0.54, n=19, P=0.017$ \\
\hline Canopy closure vs. average tree height & $r_{s}=-0.03, n=19, P=0.918$ \\
\hline Canopy closure vs. density of $\operatorname{tr}$ & $r_{s}=0.11, n=19, P=0.642$ \\
\hline \multicolumn{2}{|l|}{ (b) Beech tree characteristics } \\
\hline Number of leaves vs. average tr & $r_{s}=0.48 n=12, P=0.115$ \\
\hline Number of leaves vs & $r_{s}=0.82, n=12, P<0.001$ \\
\hline Average $t$ & $r_{s}=0.01, n=12, P=0.974$ \\
\hline Canopy closure vs. aver & $r_{s}=0.64, n=12, P=0.028$ \\
\hline Canopy closure vs. density of trees & $r_{s}=-0.53, n=12, P=0.079$ \\
\hline \multicolumn{2}{|l|}{ (c) Ash tree characteristics } \\
\hline Number of leaves vs. averag & $19, P=0.484$ \\
\hline Number of leaves vs. density of trees & $r_{s}=0.71, n=19, P<0.001$ \\
\hline Average tree height vs. density of trees & $r_{s}=-0.40, n=19, P=0.092$ \\
\hline Canopy closure vs. average tree height & $r_{s}=0.16, n=19, P=0.498$ \\
\hline Canopy closure vs. density of trees & $r_{s}=-0.30, n=19, P=0.204$ \\
\hline
\end{tabular}

(d) Sycamore forest characteristics

Soil moisture vs. soil organic matter content $\quad r_{s}=0.26, n=19, P=0.275$

Soil moisture vs. canopy closure $\quad r_{s}=0.16, n=19, P=0.522$

Canopy closure vs. soil organic matter contentr $r_{s}=-0.02, n=19, P=0.928$

Canopy closure vs. shrub richness $\quad r_{s}=-0.09, n=19, P=0.708$

Canopy closure vs. tree richness $\quad r_{s}=-0.30, n=19, P=0.916$

Tree richness vs. shrub richness $\quad r_{s}=0.15, n=19, P=0.540$

(e) Beech forest characteristics

Soil moisture vs. soil organic matter content $r_{s}=0.57, n=12, P=0.059$

Soil moisture vs. canopy closure $\quad r_{s}=0.21, n=12, P=0.514$

Canopy closure vs. soil organic matter content $r_{s}=-0.14, n=12, P=0.667$

Canopy closure vs. shrub richness $\quad r_{s}=0.14, n=12, P=0.661$

Canopy closure vs. tree richness $\quad r_{s}=-0.16, n=12, P=0.618$

Tree richness vs. shrub richness $\quad r_{s}=0.07, n=12, P=0.832$

(f) Ash forest characteristics

Soil moisture vs. soil organic matter content $\quad r_{s}=0.21, n=19, P=0.394$

Soil moisture vs. canopy closure $\quad r_{s}=0.36, n=19, P=0.135$

Canopy closure vs. soil organic matter content $r_{s}=0.15, n=19, P=0.541$

Canopy closure vs. shrub richness $\quad r_{s}=0.04, n=19, P=0.861$

Canopy closure vs. tree richness $\quad r_{s}=0.19, n=19, P=0.443$

Tree richness vs. shrub richness $\quad r_{s}=0.35, n=19, P=0.143$ 
(g) Herbivore damage (\% leaf area loss) and \% leaves infested with galls

Sycamore

Herbivore damage vs. gall infestation rate $\quad r_{s}=0.02, n=19, P=0.926$

Beech

Herbivore damage vs. gall infestation rate $\quad r_{s}=0.37, n=12, P=0.238$

Ash

Herbivore damage vs. gall infestation rate $\quad r_{s}=0.17, n=19, P=0.446$

Table S3. Summary of ANCOVA analyses examining the effects of urbanisation, forest size, tree height, total number of leaves, and density of trees (number of tree individuals $/ 4 \mathrm{~m}^{2}$ ), soil organic matter, soil moisture, canopy closure, shrub richness and tree richness, on the percentage of leaves infested by galls for (a) sycamore, (b) beech and (c) ash.

(a) Sycamore (Acer pseudoplatanus)

\begin{tabular}{|c|c|c|c|c|c|c|c|c|c|}
\hline & \multicolumn{9}{|c|}{ Percentage of leaves infested by } \\
\hline & \multicolumn{3}{|c|}{ Total galls } & \multicolumn{3}{|c|}{ Gall mites Aceria spp. } & \multicolumn{3}{|c|}{ Gall wasp Pediaspis aceris } \\
\hline & d.f. & $F$ & $P$ & d.f. & $F$ & $P$ & d.f. & $F$ & $P$ \\
\hline Degree of urbanisation & 2,3 & 11.85 & 0.038 & 2,8 & 1.21 & 0.347 & 2,10 & 1.87 & 0.204 \\
\hline Forest size & 2,3 & 1.64 & 0.833 & 2,8 & 1.01 & 0.408 & 2,10 & 2.37 & 0.143 \\
\hline Tree height ${ }^{1}$ & 1,3 & 6.80 & 0.080 & - & - & - & 1,10 & 2.44 & 0.149 \\
\hline Total number of leaves & 1,3 & 6.41 & 0.085 & 1,8 & 2.15 & 0.181 & 1,10 & 6.81 & 0.026 \\
\hline Soil organic matter & 1,3 & 6.85 & 0.079 & - & - & - & 1,10 & 3.68 & 0.084 \\
\hline Soil moisture & 1,3 & 3.98 & 0.140 & - & - & - & - & - & - \\
\hline Canopy closure & 1,3 & 6.08 & 0.090 & - & - & - & 1,10 & 7.40 & 0.022 \\
\hline Shrub richness & 1,3 & 6.04 & 0.091 & - & - & - & - & - & - \\
\hline Tree richness & 1,3 & 3.74 & 0.149 & 1,8 & 1.04 & 0.338 & - & - & - \\
\hline Urbanisation ${ }^{\star}$ forest size class & 4,3 & 2.45 & 0.244 & 4,8 & 1.00 & 0.461 & - & - & - \\
\hline
\end{tabular}

${ }^{1}$ sqrt-transformed; "-" not included in the model due to the step-wise reduction procedure. Due to inter-correlation the following variable was not included in the model: Density of trees. Significant effects $(P<0.05)$ are presented in bold.

(b) Beech (Fagus sylvatica)

\begin{tabular}{|c|c|c|c|c|c|c|c|c|c|}
\hline & \multicolumn{9}{|c|}{ Percentage of leaves infested by } \\
\hline & \multicolumn{3}{|c|}{ Total galls } & \multicolumn{3}{|c|}{ Gall midge Mikiola fagi } & \multicolumn{3}{|c|}{ Gall midge Hartigiola annulipes } \\
\hline & d.f. & $F$ & $P$ & d.f. & $F$ & $P$ & d.f. & $F$ & $\mathrm{P}$ \\
\hline Degree of urbanisation & 2,6 & 2.42 & 0.169 & 2,6 & 7.30 & 0.025 & 2,7 & 1.44 & 0.300 \\
\hline Forest size & 2,6 & 3.35 & 0.105 & 2,6 & 4.95 & 0.054 & 2,7 & 2.12 & 0.191 \\
\hline Tree height ${ }^{1}$ & 1,6 & 1.36 & 0.287 & 1,6 & 6.55 & 0.043 & - & - & - \\
\hline Density of trees ${ }^{2}$ & - & - & - & - & - & - & - & - & - \\
\hline Soil organic matter & - & - & - & - & - & - & - & - & - \\
\hline Soil moisture & - & - & - & - & - & - & - & - & - \\
\hline Tree richness & - & - & - & - & - & - & - & - & - \\
\hline
\end{tabular}

${ }_{1}$ sqrt-transformed; ${ }^{2}$ log-transformed. Due to inter-correlations the following variables were not included in the model: Total number of leaves and canopy closure. Due to limited degrees of freedom the variable shrub richness and the interaction, urbanisation ${ }^{\star}$ forest size class was not calculated. "-" not included in the model due to the step-wise reduction procedure. Significant effects $(P<0.05)$ are presented in bold.

\begin{tabular}{|c|c|c|c|c|c|c|}
\hline \multicolumn{7}{|l|}{ (c) Ash (Fraxinus excelsior) } \\
\hline & \multicolumn{6}{|c|}{ Percentage of leaves infested by } \\
\hline & \multicolumn{3}{|c|}{ Total galls } & \multicolumn{3}{|c|}{ Psyllid Psyllopsis sp } \\
\hline & d.f. & $F$ & $P$ & d.f. & $F$ & $P$ \\
\hline Degree of urbanisation & 2,10 & 1.71 & 0.230 & 2,10 & 2.36 & 0.145 \\
\hline Forest size & 2,10 & 0.93 & 0.427 & 2,14 & 1.54 & 0.262 \\
\hline Tree height $^{1}$ & 1,10 & 2.93 & 0.118 & 1,10 & 4.45 & 0.061 \\
\hline Density of trees ${ }^{2}$ & 1,10 & 1.81 & 0.208 & 1,10 & 2.27 & 0.163 \\
\hline Soil organic matter & 1,10 & 1.27 & 0.286 & 1,10 & 1.55 & 0.241 \\
\hline Soil moisture & - & - & - & - & - & - \\
\hline Canopy closure & - & - & - & - & - & - \\
\hline Shrub richness & 1,10 & 2.03 & 0.185 & 1,10 & 5.22 & 0.046 \\
\hline Tree richness & - & - & - & - & - & - \\
\hline Urbanisation ${ }^{\star}$ forest size class & s - & - & - & - & - & - \\
\hline
\end{tabular}

Table S4. Total mortality of sycamore gall wasp Pediaspis aceris (a), and gall midges Mikiola fagi (b), Hartigiola annulipes (c) and Dasineura fraxini (d). Mean values and range in (\%) are given for the different mortality factors: Parasitism, fungal attack, predation, unknown (empty galls), total mortality (sum of parasitism, fungi, predation, and unknown mortality causes), and none (original galler still present i.e. no mortality).

\begin{tabular}{lcc}
\hline Mortality factor & Mean (\%) & Range (\%) \\
\hline (a) Sycamore gall wasp Pediaspis aceris & \\
\hline Parasitism & 46.7 & $12.5-75.0$ \\
Dichatomus acerinus & 24.3 & $0-56.3$ \\
Aulogymnus aceris & 9.4 & $0-50$ \\
$\quad$ Indistinguishable parasitoid & 13.0 & $0-25.2$ \\
$\quad$ larvae & 5.7 & $0-50.0$ \\
Fungi & 1.1 & $0-6.9$ \\
Predation & 36.4 & $0-78.6$ \\
Unknown & $\mathbf{8 9 . 8}$ & $\mathbf{7 1 . 4 - 1 0 0}$ \\
Total mortality & 10.2 & $0-28.6$ \\
None & & \\
\hline
\end{tabular}




\begin{tabular}{lcc}
\hline (b) Beech gall midge Mikiola fagi & \\
\hline Parasitism & 10.1 & $0-16.7$ \\
$\quad$ Aprostecus sp. & 9.6 & $0-16.7$ \\
$\quad$ Aprostecus elongatus & 0.5 & $0-4.5$ \\
Fungi & 0 & 0 \\
Predation & 2.4 & $0-15.0$ \\
Unknown & 34.5 & $0-71.4$ \\
Total mortality & 47.0 & $0-85.7$ \\
None & 53.0 & $14.3-100$ \\
\hline \multicolumn{3}{c}{} \\
\hline (c) Beech gall midge Hartigiola annulipes \\
\hline Parasitism & 2.4 \\
$\quad$ Aprostecus sp. & 2.4 & $0-20$ \\
$\quad$ Aprostecus elongatus & 0 & $0-20$ \\
Fungi & 0 & 0 \\
Predation & 0 & 0 \\
Unknown & 77.9 & 0 \\
Total mortality & 80.3 & $52.9-97.4$ \\
None & 19.7 & $2.6-47.4$ \\
\hline & & \\
(d) Ash gall midge Dasineura fraxini & & \\
Parasitism & 0 & $0-0$ \\
Fungi & 0 & 0 \\
Predation & 0 & 0 \\
Unknown & 37.4 & $0-100$ \\
Total mortality & 37.4 & $0-100$ \\
None & 62.6 & $0-100$ \\
\hline
\end{tabular}

Table S5. Arthropod and fungal species recorded on sycamore (Acer pseudoplatanus), beech (Fagus sylvatica) and ash (Fraxinus excelsior), percentage of leaves damaged and frequency of occurrence of species-specific damage.

\begin{tabular}{|c|c|c|c|c|}
\hline Plant species & Insect/fungal species & $\%$ leaves damaged & $\%$ leaf area damaged & Frequency of occurrence ${ }^{c}$ \\
\hline \multirow{11}{*}{ Sycamore } & Heterarthrus cuneifrons ${ }^{a}$ & 10.39 & 0.49 & $12 / 19$ \\
\hline & Stigmella speciosa ${ }^{a}$ & 10.14 & 0.31 & $11 / 19$ \\
\hline & Heterarthrus aceris ${ }^{a}$ & 8.70 & 0.43 & $12 / 19$ \\
\hline & Heterarthrus leucomelaa & 0.48 & 0.03 & $2 / 19$ \\
\hline & Phyllonorycter geniculella & 1.21 & 0.02 & $4 / 19$ \\
\hline & Phyllonorycter platanoidella a & 0.48 & 0.01 & $1 / 19$ \\
\hline & Cameraria ohridella & 0.97 & 0.03 & $3 / 19$ \\
\hline & Caloptilia hemidactylella & 0.72 & 0.02 & $3 / 19$ \\
\hline & Incurvaria pectinea ${ }^{a}$ & 0.97 & 0.05 & $3 / 19$ \\
\hline & Rhytisma acerinum ${ }^{\mathrm{b}}$ & 7.49 & 0.17 & $6 / 19$ \\
\hline & Cristulariella depraedans ${ }^{\mathrm{b}}$ & 0.48 & 0.004 & $2 / 19$ \\
\hline \multirow[t]{7}{*}{ Beech } & Orchestes fagi chewing ${ }^{a}$ & 28.93 & 0.97 & $11 / 12$ \\
\hline & Orchestes fagi mining ${ }^{a}$ & 7.23 & 0.22 & $9 / 12$ \\
\hline & Phyllonorycter maestingella a & 5.66 & 0.31 & $6 / 12$ \\
\hline & Incurvaria koerneriella & 0.31 & $<0.01$ & $1 / 12$ \\
\hline & Incurvaria masculella a & 0.63 & 0.01 & $2 / 12$ \\
\hline & Bucculatrix thoracella & 0.31 & $<0.01$ & $1 / 12$ \\
\hline & Stigmella hemargyrella a & 0.31 & $<0.01$ & $1 / 12$ \\
\hline \multirow[t]{3}{*}{ Ash } & Gracillaria syringella ${ }^{a}$ & 8.33 & 1.29 & $13 / 19$ \\
\hline & Prays fraxinella ${ }^{a}$ & 4.17 & 0.13 & $8 / 19$ \\
\hline & Coleophora badiipennella a & 1.28 & 0.02 & $4 / 19$ \\
\hline
\end{tabular}

${ }^{a}$ arthropod; ${ }^{b}$ fungus; ${ }^{c}$ frequency of occurrence of species-specific damage was derived from the number of forest sites a particular species of herbivore was present, related to the number of forest sites at which the host plant was present. Abundance of species in bold were statistically analysed. The remaining species were too rare for statistical analysis. 
Table S6. Summary of ANCOVA analyses examining the effects of urbanisation, forest size, tree height, total number of leaves, density of trees (number of tree individuals $/ 4 \mathrm{~m}^{2}$ ), soil organic matter, soil moisture, canopy closure, shrub richness and tree richness, on the percentage of leaf area damage by herbivorous arthropods and fungi for (a) sycamore, (b) beech and (c) ash.

(a) Sycamore (Acer pseudoplatanus)

\begin{tabular}{|c|c|c|c|c|c|c|c|c|c|c|c|c|c|c|c|c|c|c|}
\hline & \multicolumn{3}{|c|}{ Total \% damage } & \multicolumn{3}{|c|}{$\%$ chewing } & \multicolumn{3}{|c|}{$\%$ mining } & \multicolumn{3}{|c|}{$\begin{array}{c}\text { Sawfly } \\
\text { Heterarthrus } \\
\text { aceris }\end{array}$} & \multicolumn{3}{|c|}{$\begin{array}{c}\text { Sawfly } \\
\text { Heterarthrus } \\
\text { cuneifrons }\end{array}$} & \multicolumn{3}{|c|}{$\begin{array}{c}\text { Moth } \\
\text { Stigmella } \\
\text { speciosa }\end{array}$} \\
\hline & d.f. & $F$ & $\mathrm{P}$ & d.f. & $F$ & $P$ & d.f. & $F$ & $P$ & d.f. & $F$ & $P$ & d.f. & $F$ & $P$ & d.f. & $F$ & $P$ \\
\hline Degree of urbanisation & 2,11 & 3.98 & 0.050 & 2,3 & 5.60 & 0.097 & 2,7 & 6.81 & 0.023 & 2,8 & 11.79 & 0.004 & 2,13 & 1.22 & 0.328 & 2,9 & 2.52 & 0.135 \\
\hline & 2,11 & 4.63 & 0.03 & 2,3 & 77.33 & & 2,7 & 0.01 & & 2,8 & 0.99 & 0.444 & 2,13 & 0.97 & 0.405 & 2,9 & 3.63 & 0.0 \\
\hline & 1,11 & 1.1 & & 1,3 & 9.29 & 0.0 & - & - & - & - & - & - & - & - & - & 1,9 & 1.91 & 0.200 \\
\hline & 1,11 & 1.32 & & 1,3 & 11.16 & & 1,7 & 2.17 & & - & - & - & - & - & - & 1,9 & 3.96 & 0.07 \\
\hline & - & - & - & 1,3 & & & - & - & - & 1,8 & 1.33 & 0.282 & - & - & - & 1,19 & 2.46 & 0.15 \\
\hline & - & - & - & 1,3 & & & - & - & - & - & - & - & - & - & - & 1,9 & 1.80 & 0.21 \\
\hline & 1,11 & 4.15 & 0.066 & 1,3 & 71.79 & & 1,7 & 1.99 & & 1,8 & 2.43 & 0.158 & 1,13 & 1.56 & 0.233 & - & - & - \\
\hline & - & - & - & 1,3 & 2.72 & 0.198 & 1,7 & 2.24 & 0.178 & - & - & - & - & - & - & - & - & - \\
\hline & _- & _- & - & 1,3 & 7.00 & 0.077 & - & - & - & - & - & - & - & - & - & 1,9 & 1.97 & 0.19 \\
\hline Urbanisation ${ }^{\star}$ forest size class & - & - & - & 4,3 & 14.19 & 0.027 & 4,7 & 1.21 & 0.386 & 4,8 & 1.55 & 0.276 & - & - & - & - & - & - \\
\hline
\end{tabular}

${ }^{1}$ sqrt-transformed. Due to inter-correlation the following variable was not included in the model: Density of trees. Not included in the model due to the step-wise reduction procedure. Significant effects $(P<0.05)$ are presented in bold.

\begin{tabular}{|c|c|c|c|c|c|c|c|c|c|c|c|c|}
\hline \multicolumn{13}{|c|}{ (b) Beech (Fagus sylvatica) } \\
\hline & \multicolumn{3}{|c|}{ Total \% damage } & \multicolumn{3}{|c|}{$\%$ chewing } & \multicolumn{3}{|c|}{$\%$ mining } & \multicolumn{3}{|c|}{ Weevil Orchestes fagi chewing } \\
\hline & d.f. & $F$ & $\mathrm{P}$ & d.f. & $F$ & $P$ & d.f. & $F$ & $P$ & d.f. & $F$ & $P$ \\
\hline Degree of urbanisation & 2,4 & 3.27 & 0.144 & 2,4 & 1.06 & 0.428 & 2,2 & 16.95 & 0.056 & 2,5 & 3.98 & 0.093 \\
\hline Forest size & 2,4 & 0.74 & 0.532 & 2,4 & 0.07 & 0.937 & 2,2 & 9.29 & 0.097 & 2,5 & 3.06 & 0.136 \\
\hline Tree height ${ }^{1}$ & 1,4 & 2.36 & 0.199 & - & - & - & 1,2 & 11.50 & 0.077 & 1,5 & 1.75 & 0.243 \\
\hline Density of trees ${ }^{2}$ & - & - & - & 1,4 & 2.06 & 0.224 & 1,2 & 32.09 & 0.030 & - & - & - \\
\hline Soil organic matter & 1,4 & 1.28 & 0.321 & 1,4 & 1.05 & 0.364 & 1,2 & 1.77 & 0.315 & - & - & - \\
\hline Soil moisture & - & - & - & - & - & - & 1,2 & 2.97 & 0.227 & 1,5 & 1.71 & 0.248 \\
\hline Tree richness & 1,4 & 2.7 & 0.177 & 1,4 & 1.86 & 0.244 & 1,2 & 52.35 & 0.019 & - & - & - \\
\hline
\end{tabular}

${ }_{1}$ sqrt-transformed; ${ }^{2}$ log-transformed. Due to inter-correlations the following variables were not included in the model: Total number of leaves and canopy closure. Due to limited degrees of freedom the variable shrub richness and the interaction, urbanisation ${ }^{\star}$ forest size class was not calculated. "-" not included in the model due to the step-wise reduction procedure. Significant effects $(P<0.05)$ are presented in bold.

\section{(c) Ash (Fraxinus excelsior)}

\begin{tabular}{|c|c|c|c|c|c|c|c|c|c|c|c|c|}
\hline & \multicolumn{3}{|c|}{ Total \% damage } & \multicolumn{3}{|c|}{$\%$ chewing } & \multicolumn{3}{|c|}{$\%$ mining } & \multicolumn{3}{|c|}{ Moth Gracillaria syringella } \\
\hline & d.f. & $F$ & $P$ & d.f. & $F$ & $P$ & d.f. & $F$ & $P$ & d.f. & $F$ & $P$ \\
\hline Degree of urbanisation & 2,10 & 3.41 & 0.074 & 2,9 & 0.40 & 0.683 & 2,9 & 2.84 & 0.111 & 2,7 & 2.02 & 0.203 \\
\hline Forest size & 2,10 & 0.59 & 0.574 & 2,9 & 0.30 & 0.748 & 2,9 & 0.62 & 0.562 & 2,7 & 1.21 & 0.355 \\
\hline Tree height ${ }^{1}$ & - & - & - & - & - & - & 1,9 & 1.28 & 0.287 & - & - & - \\
\hline Total number of leaves & 1,10 & 2.18 & 0.171 & 1,9 & 7.15 & 0.026 & - & - & - & - & - & - \\
\hline Soil organic matter & - & - & - & - & - & - & 1,9 & 2.46 & 0.152 & 2,7 & 2.05 & 0.195 \\
\hline Soil moisture & 1,10 & 8.25 & 0.017 & 1,9 & 7.95 & 0.020 & 1,9 & 1.08 & 0.325 & - & - & - \\
\hline Canopy closure & 1,10 & 1.97 & 0.191 & 1,9 & 1.22 & 0.297 & - & - & - & - & _- & - \\
\hline Shrub richness & - & - & - & 1,9 & 1.94 & 0.197 & 1,9 & 2.14 & 0.178 & 1,7 & 1.02 & 0.347 \\
\hline Tree richness & 1,10 & 5.52 & 0.041 & 1,9 & 1.12 & 0.318 & 1,9 & 14.51 & 0.004 & 1,7 & 11.92 & 0.012 \\
\hline Urbanisation* forest size class & - & - & - & - & - & - & - & - & - & 4,7 & 1.25 & 0.372 \\
\hline
\end{tabular}

${ }_{1}^{1}$ sqrt-transformed. Due to inter-correlation the following variable was not included in the model: Density of trees. "-" not included in the model due to the step-wise reduction procedure. Significant effects $(P<0.05)$ are presented in bold.

Table S7. Density of and percentage of the three focal tree species (sycamore, beech, and ash) in forests situated in areas with different degree of urbanisation and in forests of different sizes. Mean values $\pm S E$ are listed, $n$ indicates the forest sample size.

\begin{tabular}{|c|c|c|c|c|c|c|}
\hline & $\begin{array}{c}\text { Density of } \\
\text { sycamore saplings } \\
\text { Mean } \pm \text { SE }\end{array}$ & $\begin{array}{l}\text { Density of beech } \\
\text { saplings } \\
\text { Mean } \pm \text { SE }\end{array}$ & $\begin{array}{l}\text { Density of ash } \\
\text { saplings } \\
\text { Mean } \pm \text { SE }\end{array}$ & $\begin{array}{c}\text { Sycamore saplings } \\
(\%) \\
\text { Mean } \pm \text { SE }\end{array}$ & $\begin{array}{c}\text { Beech saplings } \\
(\%) \\
\text { Mean } \pm \text { SE }\end{array}$ & $\begin{array}{c}\text { Ash saplings } \\
(\%) \\
\text { Mean } \pm \text { SE }\end{array}$ \\
\hline \multicolumn{7}{|c|}{ Degree of urbanisation } \\
\hline Low & $19.1 \pm 10.2(n=7)$ & $18.6 \pm 5.9(n=5)$ & $6.4 \pm 2.4(n=7)$ & $42.4 \pm 11.5$ & $40.3 \pm 14.5$ & $17.2 \pm 5.7$ \\
\hline Medium & $11.2 \pm 5.6(n=5)$ & $16.0 \pm 9.4(n=3)$ & $6.0 \pm 2.0(n=5)$ & $38.1 \pm 14.3$ & $32.7 \pm 17.2$ & $29.2 \pm 13.6$ \\
\hline High & $23.6 \pm 8.6(n=7)$ & $13.0 \pm 7.3(n=4)$ & $11.6 \pm 2.7(n=7)$ & $49.3 \pm 14.9$ & $24.1 \pm 12.2$ & $26.6 \pm 6.7$ \\
\hline \multicolumn{7}{|l|}{ Forest size class } \\
\hline Small & $12.2 \pm 5.6(n=5)$ & $2.4 \pm 2.2(n=2)$ & $10.4 \pm 2.4(n=5)$ & $42.2 \pm 11.9$ & $7.4 \pm 6.8$ & $50.4 \pm 9.4$ \\
\hline Medium-sized & $28.1 \pm 11.6(n=7)$ & $12.1 \pm 6.8(n=4)$ & $7.3 \pm 2.7(n=6)$ & $59.8 \pm 11.8$ & $23.2 \pm 11.5$ & $17.0 \pm 7.0$ \\
\hline Large & $13.5 \pm 5.2(n=7)$ & $27.5 \pm 6.5(n=6)$ & $7.4 \pm 2.5(n=8)$ & $30.1 \pm 13.0$ & $56.0 \pm 13.4$ & $13.9 \pm 3.9$ \\
\hline
\end{tabular}



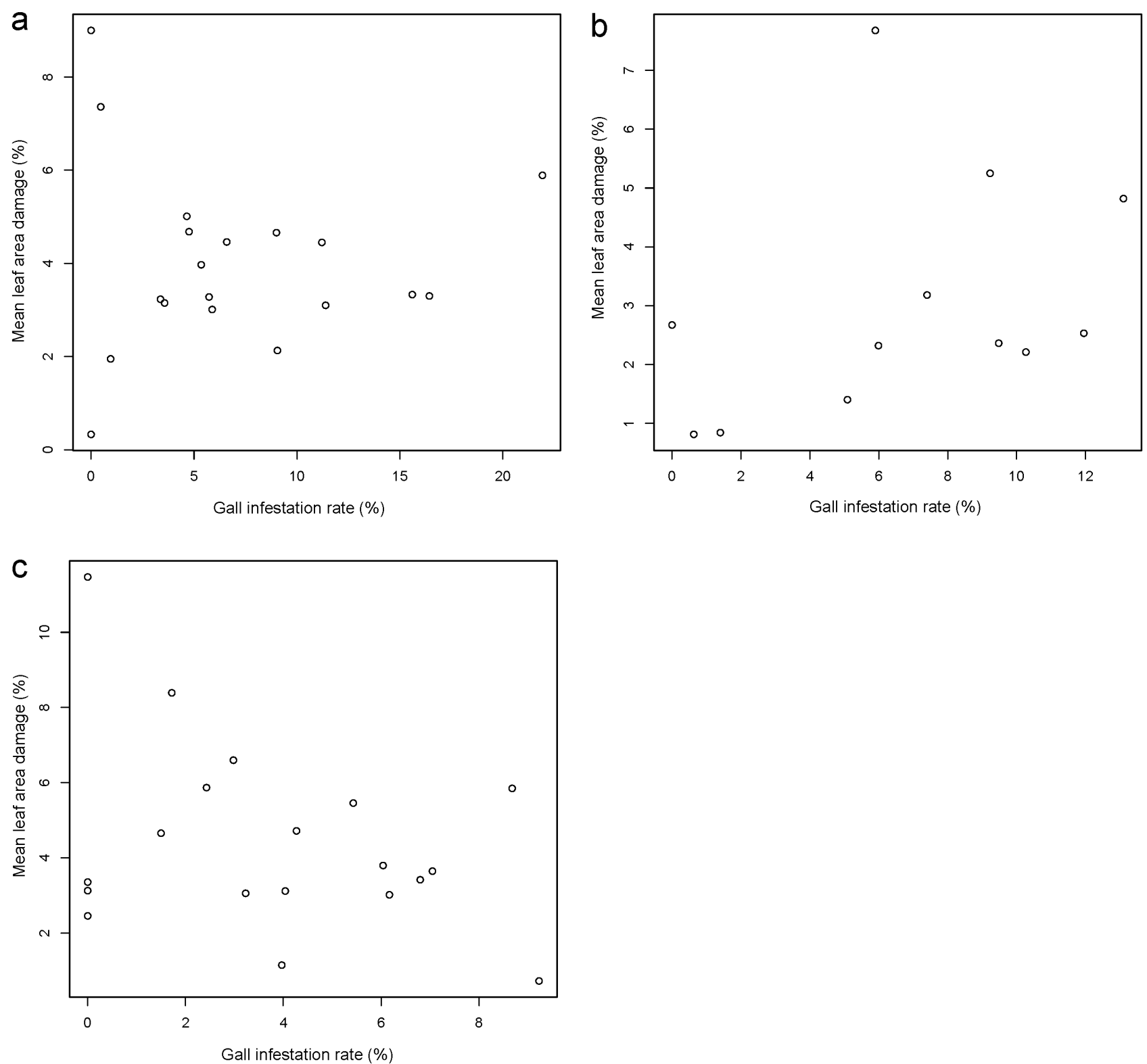

Fig. S1. Scatterplots of the relationship between \% leaf area damaged by herbivorous arthropods and gall infestation rates on leaves of (a) sycamore (Spearman rank correlation: $r_{s}=0.02, \mathrm{n}=19, P=0.926$ ), (b) beech (Spearman rank correlation: $r_{s}=0.37, \mathrm{n}=12, P=0.238$ ) and (c) ash (Spearman rank correlation: $r_{s}=-0.19, \mathrm{n}=19, P=0.446$ ). 

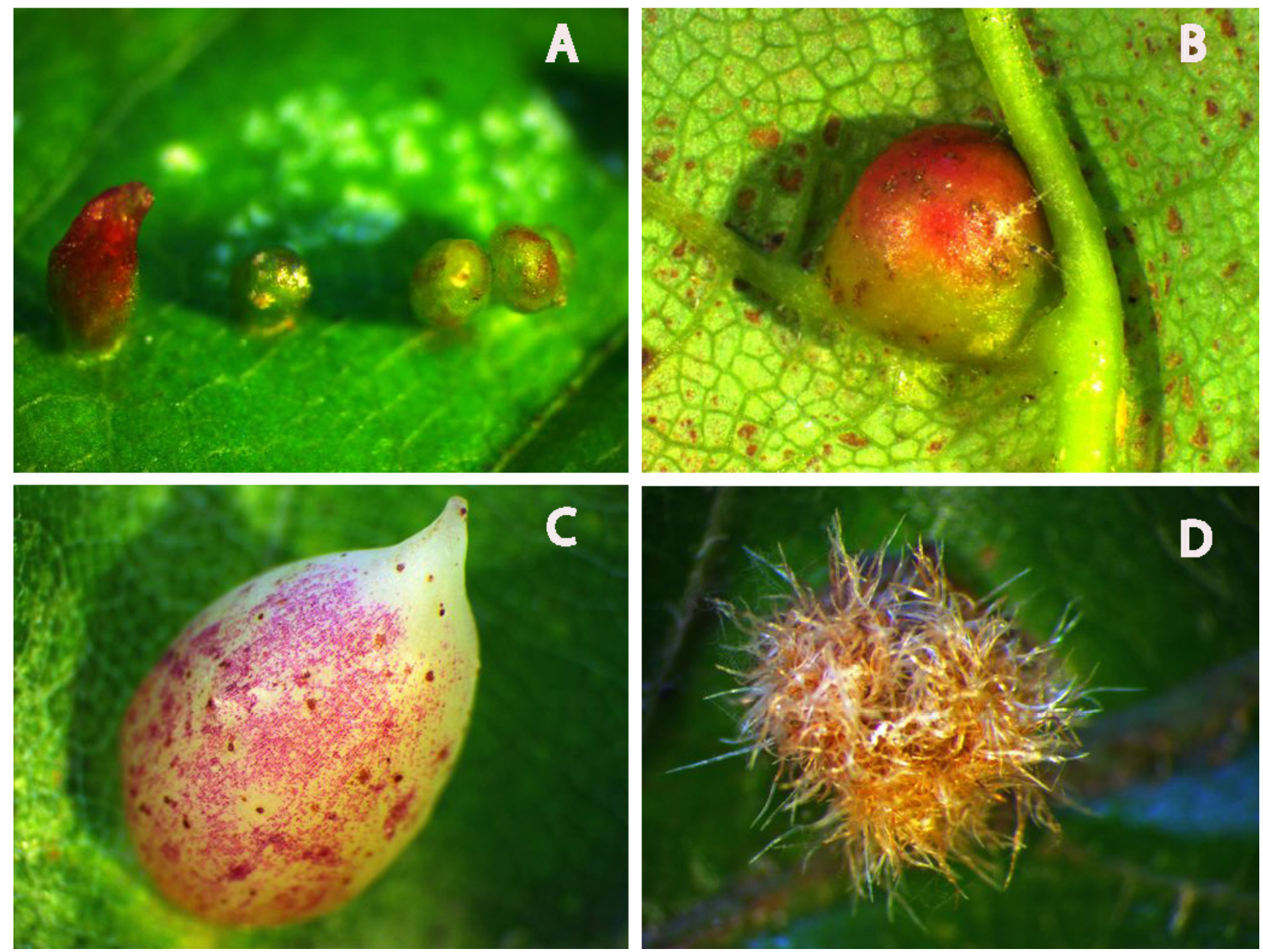

Fig. S2. Plant-galling arthropods investigated in our study. A - sycamore gall mites (Aceria spp.); B - sycamore gall wasp (Pediaspis aceris); C - beech gall midges Mikiola fagi; D - Hartigiola annulipes. 